\title{
Plastid and nuclear DNA markers reveal intricate relationships at subfamilial and tribal levels in the soapberry family (Sapindaceae)
}

\author{
Sven Buerki ${ }^{\mathrm{a}, *}$, Félix Forest ${ }^{\mathrm{b}}$, Pedro Acevedo-Rodríguez ${ }^{\mathrm{c}}$, Martin W. Callmander ${ }^{\mathrm{d}, \mathrm{e}}$, Johan A.A. Nylander ${ }^{\mathrm{f}}$, \\ Mark Harrington ${ }^{\mathrm{g}}$, Isabel Sanmartín ${ }^{\mathrm{h}}$, Philippe Küpfer ${ }^{\mathrm{a}}$, Nadir Alvarez ${ }^{\mathrm{a}}$ \\ a Institute of Biology, University of Neuchâtel, Rue Emile-Argand 11, CH-2009 Neuchâtel, Switzerland \\ ${ }^{\mathrm{b}}$ Molecular Systematics Section, Jodrell Laboratory, Royal Botanic Gardens, Kew, Richmond, Surrey TW9 3DS, United Kingdom \\ ${ }^{\mathrm{c}}$ Department of Botany, Smithsonian Institution, National Museum of Natural History, NHB-166, Washington, DC 20560, USA \\ ${ }^{\mathrm{d}}$ Missouri Botanical Garden, PO Box 299, 63166-0299, St. Louis, MO, USA \\ e Conservatoire et Jardin botaniques de la ville de Genève, ch. de l'Impératrice 1, CH-1292 Chambésy, Switzerland \\ ${ }^{\mathrm{f}}$ Department of Botany, Stockholm University, SE-10691, Stockholm, Sweden \\ ${ }^{\mathrm{g}}$ School of Marine and Tropical Biology, James Cook University, PO Box 6811, Cairns, Qld 4870, Australia \\ ${ }^{\mathrm{h}}$ Department of Biodiversity and Conservation, Real Jardin Botanico - CSIC, Plaza de Murillo 2, 28014 Madrid, Spain
}

\section{A R T I C L E I N F O}

\section{Article history:}

Received 21 May 2008

Revised 27 November 2008

Accepted 23 January 2009

Available online 30 January 2009

\section{Keywords:}

Aceraceae

Classification

Hippocastanaceae

Molecular phylogeny

Paraphyly

Polyphyly

Sapindaceae

Xanthoceras

\begin{abstract}
A B S T R A C T
The economically important soapberry family (Sapindaceae) comprises about 1900 species mainly found in the tropical regions of the world, with only a few genera being restricted to temperate areas. The infrafamilial classification of the Sapindaceae and its relationships to the closely related Aceraceae and Hippocastanaceae - which have now been included in an expanded definition of Sapindaceae (i.e., subfamily Hippocastanoideae) - have been debated for decades. Here we present a phylogenetic analysis of Sapindaceae based on eight DNA sequence regions from the plastid and nuclear genomes and including 85 of the 141 genera defined within the family. Our study comprises 997 new sequences of Sapindaceae from 152 specimens. Despite presenting $18.6 \%$ of missing data our complete data set produced a topology fully congruent with the one obtained from a subset without missing data, but including fewer markers. The use of additional information therefore led to a consistent result in the relative position of clades and allowed the definition of a new phylogenetic hypothesis. Our results confirm a high level of paraphyly and polyphyly at the subfamilial and tribal levels and even contest the monophyletic status of several genera. Our study confirms that the Chinese monotypic genus Xanthoceras is sister to the rest of the family, in which subfamily Hippocastanoideae is sister to a clade comprising subfamilies Dodonaeoideae and Sapindoideae. On the basis of the strong support demonstrated in Sapindoideae, Dodonaeoideae and Hippocastanoideae as well as in 14 subclades, we propose and discuss informal groupings as basis for a new classification of Sapindaceae.
\end{abstract}

(c) 2009 Elsevier Inc. All rights reserved.

\section{Introduction}

The soapberry family (Sapindaceae: Sapindales) comprising c. 1900 species (Acevedo-Rodríguez, personal communication), has a predominantly pantropical distribution with the occurrence of some taxa in temperate areas (e.g., Acer, Aesculus, Atalaya, Diplopeltis, Dodonaea). Sapindaceae include many economically important species used for their fruits [e.g., guarana (Paullinia cupana), litchi (Litchi chinensis), longan (Dimocarpus longan), pitomba (Talisia esculenta) and rambutan (Nephelium lappaceum)], wood [e.g., buckeyes (Aesculus)] or as ornamentals (Koelreuteria, Ungnadia).

The circumscription of the family as well as the relationships among subfamilial entities have been widely challenged since the

\footnotetext{
* Corresponding author. Fax: +41 327183001

E-mail address: sven.buerki@unine.ch (S. Buerki).
}

very first worldwide treatment of Sapindaceae sensu stricto (s.s.) (including subfamilies Sapindoideae and Dodonaeoideae) proposed by Radlkofer (1890, 1933; for a review see Harrington et al., 2005). For instance, several genera within the Sapindoideae (e.g., Tinopsis and Plagioscyphus from Madagascar; Capuron, 1969) were shown to be morphologically transitional between tribes described by Radlkofer (1933), which prevented the recognition of unequivocal tribes. Within Sapindaceae s.s. the higher taxonomic entities (subfamilies and tribes) were originally defined by Radlkofer (1933) based on the number and type of ovules per locule, the fruit morphology, the presence or not of an arillode, the leaf type and the cotyledon shape. On the basis of macromorphological and palynological characters, Müller and Leenhouts (1976) revised the classification of Radlkofer (1933). They recognized eight major pollen types (A-H) and several subtypes (e.g., type-A1), mainly based on their shape and characteristics of the aperture (Fig. 1). 

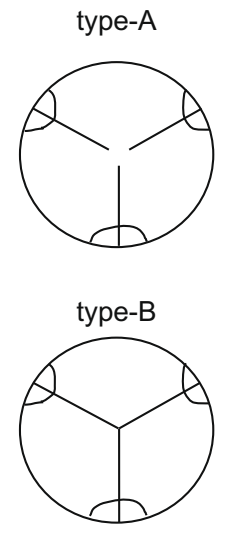

type-C2
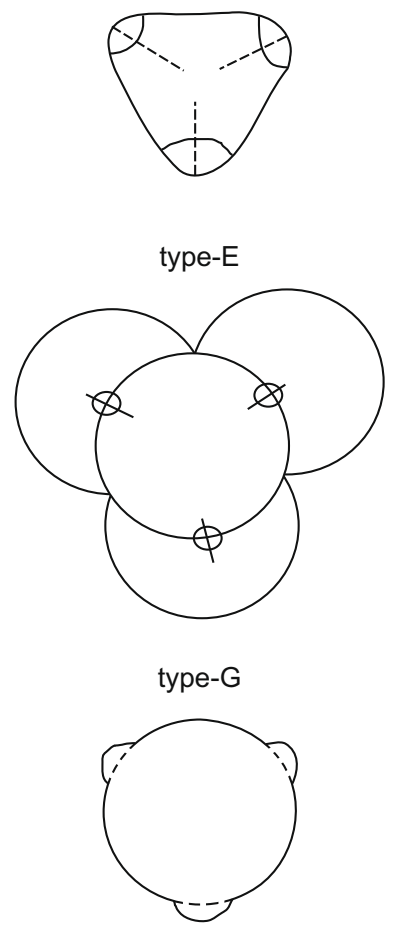

Fig. 1. Schematic representation of pollen types in Sapindaceae following Müller and Leenhouts (1976). See text for explanations regarding the morphological differentiation between pollen types.

The pollen grains in Sapindaceae are triporate [the diporate type-D pollen of Lophostigma recognized by Müller and Leenhouts (1976) was wrongly identified; see Acevedo-Rodríguez (1993a)]. Spherical pollen shape occurs in the majority of species (e.g., types A, B and $\mathrm{H}$ ), whereas a triangular (type-C) or oblate (type-A1) shape is more restricted. The colpi may be absent (e.g., type-G) or parasyncolporate (e.g., type-A) to syncolporate (e.g., type-B) (Fig. 1). Based on those characters Müller and Leenhouts (1976) rearranged the nine tribes of Sapindoideae recognized by Radlkofer (1933) into three taxonomically unranked groups characterized by their distribution, the presence or absence of an arillode surrounding the seed and the pollen types [i.e., group A comprised Sapindeae, Lepisantheae (incl. Aphanieae) and Melicocceae; group B comprised Schleichereae, Nephelieae and Cupanieae; group C comprised Paullinieae and Thouinieae]. They did not, however, modify the classification within the Dodonaeoideae and maintained the five tribes described by Radlkofer (i.e., Cossinieae, Dodonaeeae, Doratoxyleae, Harpullieae and Koelreuterieae, 1933). Furthermore, Müller and
Leenhouts (1976) kept the predominantly temperate families Aceraceae and Hippocastanaceae separate from the rest of Sapindaceae. The circumscription of Sapindaceae has been debated ever since. Takhtajan (1987), Cronquist (1988) and Dahlgren (1989) maintained Aceraceae and Hippocastanaceae separate from Sapindaceae, whereas broader concepts of the family have been adopted by several workers (e.g., Umadevi and Daniel, 1991; Judd et al., 1994; Gadek et al., 1996; Savolainen et al., 2000; Thorne, 2000, 2007; APGII, 2003).

Building on a large-scale molecular phylogenetic analysis of Sapindales (Gadek et al., 1996), Harrington et al. (2005) published the first molecular phylogeny of Sapindaceae sensu lato (s.l.) (including Aceraceae and Hippocastanaceae) inferred from the plastid genes $r b c L$ and matK. Their phylogeny recognized the subdivision of Sapindaceae s.l. into four supported lineages, a monotypic Xanthoceroideae, Hippocastanoideae (including Aceraceae, Hippocastanaceae and Handeliodendron), a more narrowly defined Dodonaeoideae and Sapindoideae (including Koelreuteria and Ungnadia). Relationships between these four lineages remained weakly supported. Confirming previous works based on morphological features, Harrington et al. (2005) highlighted the paraphyletic or polyphyletic nature of several tribes described by Radlkofer (1933).

According to the new assessment of the Sapindaceae s.l. proposed by Thorne (2007; mainly based on Harrington et al., 2005) and a broad review of currently described taxa, it is now widely accepted that the c. 1900 species of this cosmopolitan family are divided into 141 genera (see Table 1; Acevedo-Rodríguez, personal communication). Even if Harrington et al. (2005) covered worldwide representatives of Sapindaceae s.l., the sampling (64 of the 141 genera, i.e., $45.4 \%$ ) and the number of markers were not sufficient to assess the relationships among and within the major lineages of the family with confidence. In this study we provide a new assessment of the phylogenetic relationships within Sapindaceae s.l. based on $60.3 \%$ of the generic diversity ( 85 of the 141 genera) and including the previously unsampled tribe Cossinieae. The analysis is based on a combination of one nuclear (ITS region; ITS1, $5.8 S$, ITS2) and seven plastid (coding matK and rpoB; non coding trnL intron and intergenic spacers trnD-trnT, trnK-matK, trnL-trnF and $t r n S$-trnG) markers. Coding plastid regions have proven to be useful in addressing phylogenetic relationships at higher taxonomic levels (e.g., Clayton et al., 2007; Muellner et al., 2006, 2007; Harrington et al., 2005), whereas noncoding regions (introns and intergenic spacers) were shown to be more useful at lower taxonomic ranks (Baldwin, 1992; Soltis and Soltis, 1998). The combination of several markers from both nuclear and plastid genomes as well as coding and non coding regions are expected to improve the resolution of phylogenetic relationships within the family. In this study, our objectives are (1) to examine the relationships between the traditionally defined Aceraceae and Hippocastanaceae with the rest of Sapindaceae, (2) to evaluate the tribal concepts of Radlkofer (1933) and Müller and Leenhouts (1976), (3) to examine phylogenetic relationships among taxa in light of characters traditionally used to define the higher level groupings in Sapindaceae s.l. (e.g., number of ovules per locule, pollen morphology, leaf type and presence/absence of an arillode) and (4) to propose a new preliminary infrafamilial classification for Sapindaceae s.l.

In addition of being a challenging family at the taxonomic level, the amplification of molecular markers in Sapindaceae s.l. is made difficult by several mutations occurring in flanking regions of widely used plastid and nuclear regions such as matK (Harrington et al., 2005) and ITS (Edwards and Gadek, 2001). Those mutations complicate the compilation of multilocus data sets without missing data. Maximizing taxa and markers representation to provide a reliable phylogenetic hypothesis inferred from nuclear and plastid genomes is required to propose a new classification 
Table 1

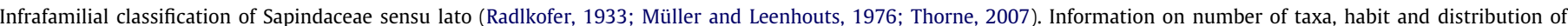

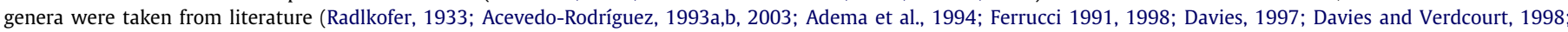

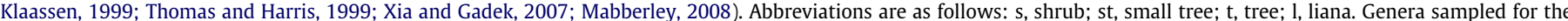
phylogenetic analysis of Sapindaceae are indicated in bold and genera found to be either paraphyletic or polyphyletic are identified by an asterisk $(*)$.

\begin{tabular}{|c|c|c|c|c|c|}
\hline & Genera & Author & Taxa & Habit & Distribution \\
\hline \multicolumn{6}{|l|}{ Sapindaceae Jussieu 104/141 genera, 205/1886 species } \\
\hline \multirow{2}{*}{$\begin{array}{l}\text { Dodonaeoideae Burnett Cossinieae Bl. (Cos) } 2 / 2 \\
\text { genera, } 3 / 7 \text { species }\end{array}$} & Cossinia & Comm. ex & 4 & s-st & Mascarenes, New Caledonia, E Australia, Fiji \\
\hline & Llagunoa & $\begin{array}{l}\text { Ruíz \& } \\
\text { Pavón }\end{array}$ & 3 & s-st & W tropical South America \\
\hline \multirow[t]{5}{*}{ Dodonaeeae Kunth (Dod) 3/5 genera, 5/78 species } & Diplopeltis & Endl. & 5 & $\mathrm{~s}-\mathrm{t}$ & NW Australia \\
\hline & Distichostemon & F. Muell. & 6 & s & Australia \\
\hline & Dodonaea & Miller & c. 65 & s-st & $\begin{array}{l}\text { Mainly in Australia, Malesia, New Guinea, Carribean and } \\
\text { Madagascar }\end{array}$ \\
\hline & Hirania & Thulin & 1 & $\mathrm{~S}$ & Somalia \\
\hline & Loxodiscus & Hook. f. & 1 & $\mathrm{~s}$ & New Caledonia \\
\hline \multirow[t]{7}{*}{ Doratoxyleae Radlk. (Dor) 6/9 genera, 8/22 species } & Averrhoidium & Baillon & 2 & $\mathrm{t}$ & South America \\
\hline & Doratoxylon & $\begin{array}{l}\text { Thou. ex } \\
\text { Hook. f. }\end{array}$ & 5 & st- $\mathrm{t}$ & Madagascar and Mascarenes Islands \\
\hline & Euchorium & $\begin{array}{l}\text { Eckman \& } \\
\text { Radlk. }\end{array}$ & 1 & $\mathrm{t}$ & Cuba \\
\hline & Exothea & Macfad. & 3 & $\mathrm{t}$ & West Indies, Central America and Florida \\
\hline & Filicium & $\begin{array}{l}\text { Thw ex } \\
\text { Hook. f. }\end{array}$ & 3 & s-st & E Africa, Madagascar and SE India \\
\hline & Ganophyllum & Blume & 2 & $\mathrm{t}$ & $\begin{array}{l}\text { W and C Africa, Andamans and Nicobars to NE Australia and } \\
\text { Solomon Islands to Malesia }\end{array}$ \\
\hline & Hippobromus & $\begin{array}{l}\text { Ecklon \& } \\
\text { Zeyher }\end{array}$ & 1 & $\mathrm{t}$ & South Africa \\
\hline \multirow{8}{*}{$\begin{array}{l}\text { Dodonaeoideae Burnett Harpullieae Radlk. (Har) 6/6 } \\
\text { genera, 8/34 species }\end{array}$} & Hypelate & P. Browne & 1 & s-st & West Indies and Florida \\
\hline & Zanha & Hiern & 4 & $\mathrm{t}$ & Tropical Africa and Madagascar \\
\hline & Arfeuillea & $\begin{array}{l}\text { Pierre ex } \\
\text { Radlk. }\end{array}$ & 1 & $\mathrm{t}$ & SE Asia \\
\hline & Conchopetalum & Radlk. & 2 & st-t & Madagascar \\
\hline & Eurycorymbus & $\begin{array}{l}\text { Handel- } \\
\text { Mazzetti }\end{array}$ & 1 & $\mathrm{t}$ & China \\
\hline & Harpullia & Roxb. & 26 & s-st & $\begin{array}{l}\text { India, SE China, Malesia to Australia, New Caledonia and } \\
\text { Pacific Islands }\end{array}$ \\
\hline & Magonia & A. St. Hil. & 1 & $\mathrm{t}$ & South America \\
\hline & Majidea & $\begin{array}{l}\text { J. Kirk ex } \\
\text { Oliver }\end{array}$ & 3 & $\mathrm{t}$ & Tropical Africa and Madagascar \\
\hline \multirow{5}{*}{$\begin{array}{l}\text { Hippocastanoideae Burnett 5/5 genera, 18/129 } \\
\text { species }\end{array}$} & Acer & L. & 111 & $s-t$ & $\mathrm{~N}$ temperate \& tropical mountains \\
\hline & Aesculus & L. & 13 & $\mathrm{t}$ & SE Europe, India, E Asia and N America \\
\hline & Billia & Peyr. & 2 & $s-t$ & S Mexico to Tropical South America \\
\hline & Dipteronia & Oliver & 2 & s-st & C\&S China \\
\hline & Handeliodendron & Rehder & 1 & $s-t$ & China - deciduous \\
\hline \multirow{15}{*}{$\begin{array}{l}\text { Sapindoideae Burnett Cupanieae Reichenb. (Cup) 36/ } \\
48 \text { genera, 79/462 species }\end{array}$} & Amesiodendron & $\mathrm{Hu}$ & 1 & $\mathrm{t}$ & China, Indo-China and Malesia \\
\hline & Aporrhiza & Radlk. & 6 & $\mathrm{t}$ & Tropical Africa \\
\hline & Arytera & Blume & c. 28 & $\mathrm{~s}-\mathrm{t}$ & Indo-Malesia to E Australia and Pacific \\
\hline & Blighia & Koenig & 4 & $\mathrm{t}$ & Tropical Africa \\
\hline & Blighiopsis & $\begin{array}{l}\text { Van der } \\
\text { Vecken }\end{array}$ & 1 & $\mathrm{t}$ & Tropical Africa \\
\hline & Blomia & Miranda & 1 & $\mathrm{t}$ & Mexico \\
\hline & Cnesmocarpon & Adema & 4 & s-st & Australia and Papua New Guinea \\
\hline & Cupania & L. & c. 45 & $s-t$ & Tropical America \\
\hline & Cupaniopsis & Radlk. & 60 & s-st & $\begin{array}{l}\text { Malesia, New Guinea, N-E Australia, Pacific islands, New } \\
\text { Caledonia }\end{array}$ \\
\hline & Dictyoneura & Blume & 3 & s-st & Malesia \\
\hline & Dilodendron & Radlk. & 1 & $\mathrm{t}$ & South America \\
\hline & Diploglottis & Hook.f. & 12 & $\mathrm{t}$ & NE Australia and Papua New Guinea \\
\hline & Diplokeleba & N.E. Br. & 2 & st & South America \\
\hline & Elattostachys & $\begin{array}{l}\text { (Blume) } \\
\text { Radlk. }\end{array}$ & c. 20 & $s-\mathrm{t}$ & Malesia to Australia, W Pacific \\
\hline & Eriocoelum & Hook. f. & c. 10 & $\mathrm{t}$ & Tropical Africa \\
\hline \multirow[t]{7}{*}{ Sapindoideae Burnett Cupanieae Reichenb. (Cup) } & Euphorianthus & Radlk. & 1 & $\mathrm{t}$ & E Malesia \\
\hline & Gloeocarpus & Radlk. & 1 & $\mathrm{t}$ & Philippines \\
\hline & Gongrodiscus & Radlk. & 3 & $s-t$ & New Caledonia \\
\hline & Gongrospermum & Radlk. & 1 & $\mathrm{t}$ & Philippines \\
\hline & Guioa* & Cav. & 65 & $s-\mathrm{t}$ & SE Asia, Malesia to E Australia; Pacific and New Caledonia \\
\hline & Haplocoelopsis & F.G. Davies & 1 & $s-t$ & E Africa \\
\hline & Jagera & Blume & 2 & $\mathrm{t}$ & New Guinea and Australia \\
\hline
\end{tabular}


Table 1 (continued)

\begin{tabular}{|c|c|c|c|c|c|}
\hline & Genera & Author & Taxa & Habit & Distribution \\
\hline & $\begin{array}{l}\text { Laccodiscus } \\
\text { Lepiderema } \\
\text { Lepidopetalum } \\
\text { Lynchodiscus } \\
\text { Matayba } \\
\text { Mischarytera } \\
\text { Mischocarpus } \\
\text { Molinaea } \\
\text { Neotina } \\
\text { Paranephelium } \\
\text { Pavieasia } \\
\text { Pentascyphus } \\
\text { Phyllotrichum } \\
\text { Pseudima } \\
\text { Rhysotoechia } \\
\text { Sarcopteryx } \\
\text { Sarcotoechia } \\
\text { Scyphonychium } \\
\text { Sisyrolepis } \\
\text { Storthocalyx } \\
\text { Synima } \\
\text { Tina } \\
\text { Toechima } \\
\text { Trigonachras } \\
\text { Tripterodendron } \\
\text { Vouarana }\end{array}$ & $\begin{array}{l}\text { Radlk. } \\
\text { Radlk. } \\
\text { Blume } \\
\text { Radlk. } \\
\text { Aublet. } \\
\text { (Radlk.) H. Turner } \\
\text { Blume } \\
\text { Comm. ex. Juss. } \\
\text { Capuron } \\
\text { Miq. } \\
\text { Pierre } \\
\text { Radlk. } \\
\text { Thorel ex Lecompte } \\
\text { Radlk. } \\
\text { Radlk. } \\
\text { Radlk. } \\
\text { Radlk. } \\
\text { Radlk. } \\
\text { Radlk. } \\
\text { Radlk. } \\
\text { Radlk. } \\
\text { Roem. \& Schult. } \\
\text { Radlk. } \\
\text { Radlk. } \\
\text { Radlk. } \\
\text { Aublet. }\end{array}$ & $\begin{array}{l}4 \\
8 \\
7 \\
6 \\
\text { c. } 56 \\
3 \\
15 \\
9 \\
2 \\
4 \\
3 \\
1 \\
1 \\
3 \\
14 \\
12 \\
11 \\
1 \\
1 \\
4 \\
2 \\
6 \\
7 \\
8 \\
1 \\
1\end{array}$ & $\begin{array}{l}s-s t \\
t \\
s-t \\
t \\
s-t \\
t \\
s-t \\
s-t \\
t \\
s-t \\
t \\
t \\
t \\
t \\
s-t \\
s-t \\
t \\
t \\
s-s t \\
s \\
t \\
s-s t \\
t \\
t \\
t \\
t\end{array}$ & $\begin{array}{l}\text { W Africa } \\
\text { Australia and New Guinea } \\
\text { India, NE Australia and Solomon Islands } \\
\text { W Tropical Africa } \\
\text { Tropical America } \\
\text { Australia, Papua New Guinea } \\
\text { SE Asia, Malesia to Australia } \\
\text { Madagascar, Mascarenes } \\
\text { Madagascar } \\
\text { SE Asia and W Malesia } \\
\text { S China, N Vietnam } \\
\text { Guyana } \\
\text { SE Asia } \\
\text { South America } \\
\text { Australia, New Guinea, Malesia } \\
\text { Malesia, New Guinea and E Australia } \\
\text { NE Australia and New Guinea } \\
\text { NE Brazil } \\
\text { Thailand } \\
\text { New Caledonia } \\
\text { Australia and SE New Guinea } \\
\text { Madagascar } \\
\text { Australia and New Guinea } \\
\text { Malesia } \\
\text { Brazil } \\
\text { NE South America }\end{array}$ \\
\hline $\begin{array}{l}\text { Sapindoideae Burnett Koelreuterieae Radlk. (Koe) 2/4 } \\
\text { genera, } 2 / 15 \text { species }\end{array}$ & $\begin{array}{l}\text { Erythrophysa } \\
\text { Koelreuteria } \\
\text { Sinoradlkofera } \\
\text { Stocksia }\end{array}$ & $\begin{array}{l}\text { E. Mey ex Arnott } \\
\text { Laxmann } \\
\text { F.G. Mey } \\
\text { Benth. }\end{array}$ & $\begin{array}{l}9 \\
3 \\
2 \\
1\end{array}$ & $\begin{array}{l}\mathrm{s} \\
\mathrm{t} \\
\mathrm{st} \\
\mathrm{s}\end{array}$ & $\begin{array}{l}\text { Africa and Madagascar } \\
\text { S China, Japan } \\
\text { China and N Vietnam } \\
\text { E Iran, Afghanistan }\end{array}$ \\
\hline Lepisantheae Radlk. (Lep) 4/10 genera, 7/97 species & $\begin{array}{l}\begin{array}{l}\text { Chonopetalum } \\
\text { Chytranthus } \\
\text { Glenniea } \\
\text { Lepisanthes }\end{array} \\
\text { Namataea } \\
\text { Pancovia } \\
\text { Placodiscus } \\
\text { Pseudopancovia } \\
\text { Radlkofera } \\
\text { Zollingeria }\end{array}$ & $\begin{array}{l}\text { Radlk. } \\
\text { Hook. f. } \\
\text { Hook. f. } \\
\text { Blume } \\
\text { D.W. Thomas \& D.J. } \\
\text { Harris } \\
\text { Willd. } \\
\text { Radlk. } \\
\text { Pellegrin } \\
\text { Gilg. } \\
\text { Kurz }\end{array}$ & $\begin{array}{l}1 \\
\text { c. } 30 \\
8 \\
24 \\
1\end{array}$ & $\begin{array}{l}\mathrm{t} \\
\mathrm{st} \\
\mathrm{s}-\mathrm{t}\end{array}$ & $\begin{array}{l}\text { Tropical W Africa } \\
\text { Africa } \\
\text { Tropical Africa, Madagascar, Sri Lanka, Malesia } \\
\text { Tropical Africa, Madagascar, S-SE Asia, Malesia and } \\
\text { NW Australia } \\
\text { Cameroon } \\
\text { Tropical Africa } \\
\text { Tropical W Africa } \\
\text { Tropical W Africa } \\
\text { Tropical Africa } \\
\text { SE Asia and Malesia }\end{array}$ \\
\hline Melicocceae Blume (Mel) 5/5 genera, $8 / 67$ species & $\begin{array}{l}\text { Castanospora } \\
\text { Melicoccus } \\
\text { Talisia } \\
\text { Tristira } \\
\text { Tristiropsis }\end{array}$ & $\begin{array}{l}\text { F. Muell. } \\
\text { P. Browne } \\
\text { Aublet } \\
\text { Radlk. } \\
\text { Radlk. }\end{array}$ & $\begin{array}{l}1 \\
10 \\
52 \\
1 \\
3\end{array}$ & $\begin{array}{l}\mathrm{t} \\
\mathrm{t} \\
\mathrm{t}-\mathrm{t} \\
\mathrm{t}\end{array}$ & $\begin{array}{l}\text { NE Australia } \\
\text { Tropical America } \\
\text { Tropical America } \\
\text { Malesia } \\
\text { Pacific Ocean, Australia, Solomon Islands and } \\
\text { Malesia }\end{array}$ \\
\hline Nephelieae Radlk. (Nep) 11/12 genera, $15 / 77$ species & $\begin{array}{l}\text { Alectryon } \\
\text { Cubilia } \\
\text { Dimocarpus } \\
\text { Litchi } \\
\text { Nephelium } \\
\text { Otonephelium }\end{array}$ & $\begin{array}{l}\text { Blume } \\
\text { Lour. } \\
\text { Sonn. } \\
\text { L. } \\
\text { Radlk. }\end{array}$ & $\begin{array}{l}\text { c. } 30 \\
1 \\
6 \\
1 \\
22 \\
1\end{array}$ & $\begin{array}{l}\mathrm{t} \\
\mathrm{s}-\mathrm{t} \\
\mathrm{t} \\
\mathrm{t}\end{array}$ & $\begin{array}{l}\text { E Malesia, Australia, New Zealand, New Caledonia, } \\
\text { to Hawaii } \\
\text { Malesia } \\
\text { S and SE Asia and Australia } \\
\text { Tropical China to W Malesia } \\
\text { SE Asia and Malesia } \\
\text { India }\end{array}$ \\
\hline Sapindoideae Burnett Nephelieae Radlk. (Nep) & $\begin{array}{l}\text { Pappea } \\
\text { Podonephelium } \\
\text { Pometia } \\
\text { Smelophyllum } \\
\text { Stadmania } \\
\text { Xerospermum }\end{array}$ & $\begin{array}{l}\text { Eckl. \& Zeyh. } \\
\text { Baillon } \\
\text { Forst. \& Forst. } \\
\text { Radlk. } \\
\text { Lam. } \\
\text { Blume }\end{array}$ & $\begin{array}{l}1 \\
4 \\
2 \\
1 \\
6 \\
2\end{array}$ & $\begin{array}{l}\text { s-t } \\
\text { s-t } \\
\text { t } \\
\mathrm{t} \\
\mathrm{t}\end{array}$ & $\begin{array}{l}\text { Tropical E to S Africa } \\
\text { New Caledonia } \\
\text { Malesia and Pacific Islands } \\
\text { South Africa } \\
\text { Tropical E Africa, S Africa, Madagascar and } \\
\text { Mascarenes Islands } \\
\text { Indochinese Peninsula and Malesia }\end{array}$ \\
\hline Paullinieae Kunth (Pau) 4/7 genera, $15 / 466$ species & $\begin{array}{l}\text { Houssayanthus } \\
\text { Lophostigma } \\
\text { Paullinia }\end{array}$ & $\begin{array}{l}\text { L. } \\
\text { Hunz. } \\
\text { Radlk. } \\
\text { L. }\end{array}$ & $\begin{array}{l}\text { c. } 12 \\
3 \\
2 \\
\text { c. } \\
200\end{array}$ & $\begin{array}{l}1 \\
s-1 \\
1 \\
1\end{array}$ & $\begin{array}{l}\text { Tropical and subtropical America; } 1 \text { sp. extending } \\
\text { to Africa } \\
\text { South America } \\
\text { South America } \\
\text { Tropical America and one pantropical sp. }\end{array}$ \\
\hline & Serjania & Miller & $\begin{array}{l}200 \\
226\end{array}$ & 1 & Tropical America \\
\hline & $\begin{array}{l}\text { Thinouia } \\
\text { Urvillea }\end{array}$ & $\begin{array}{l}\text { Triana \& Planchon } \\
\text { Kunth }\end{array}$ & $\begin{array}{l}9 \\
14\end{array}$ & $\begin{array}{l}1 \\
1\end{array}$ & $\begin{array}{l}\text { Tropical America } \\
\text { Tropical America }\end{array}$ \\
\hline
\end{tabular}


Table 1 (continued)

\begin{tabular}{|c|c|c|c|c|c|c|}
\hline & Genera & Author & & Taxa & Habit & Distribution \\
\hline Sapindeae DC (Sap) 3/7 genera, 12/89 species & $\begin{array}{l}\text { Atalaya } \\
\text { Deinbollia } \\
\text { Hornea } \\
\text { Porocystis } \\
\text { Sapindus } \\
\text { Thouinidium } \\
\text { Toulicia }\end{array}$ & $\begin{array}{l}\text { Blume } \\
\text { Schumach. \& Thonn. } \\
\text { Baker } \\
\text { Radlk. } \\
\text { L. } \\
\text { Radlk. } \\
\text { Aublet }\end{array}$ & c. & $\begin{array}{l}12 \\
40 \\
1 \\
2 \\
13 \\
7 \\
14\end{array}$ & $\begin{array}{l}s t \\
t \\
s-t \\
s-t \\
t \\
s-t \\
t\end{array}$ & $\begin{array}{l}\text { Australia, New Guinea and S Africa } \\
\text { Tropical Africa and Madagascar } \\
\text { Mauritius } \\
\text { Tropical South America } \\
\text { Tropical to warm temperate regions } \\
\text { Mexico and West Indies } \\
\text { South America }\end{array}$ \\
\hline Schleichereae Radlk. (Sch) 8/12 genera, $12 / 55$ species & $\begin{array}{l}\text { Beguea } \\
\text { Bizonula } \\
\text { Camptolepis } \\
\text { Chouxia } \\
\text { Haplocoelum } \\
\text { Lecaniodiscus } \\
\text { Macphersonia } \\
\text { Plagioscyphus } \\
\text { Pseudopteris }\end{array}$ & $\begin{array}{l}\text { Capuron } \\
\text { Pellegrin } \\
\text { Radlk. } \\
\text { Capuron } \\
\text { Radlk. } \\
\text { Planch. ex Benth. } \\
\text { Blume } \\
\text { Radlk. } \\
\text { Baill. }\end{array}$ & & $\begin{array}{l}1 \\
1 \\
4 \\
6 \\
\text { c. } 6 \\
3 \\
8 \\
10 \\
3\end{array}$ & $\begin{array}{l}\mathrm{t} \\
\mathrm{t} \\
\mathrm{t} \\
\mathrm{s}-\mathrm{st} \\
\mathrm{st}-\mathrm{t} \\
\mathrm{st} \\
\mathrm{s}-\mathrm{t} \\
\mathrm{st}-\mathrm{t} \\
\mathrm{s}\end{array}$ & $\begin{array}{l}\text { Madagascar } \\
\text { Tropical Africa } \\
\text { E Africa and Madagascar } \\
\text { Madagascar } \\
\text { Tropical Africa and Madagascar } \\
\text { Tropical Africa } \\
\text { Tropical E Africa and Madagascar } \\
\text { Madagascar } \\
\text { Madagascar }\end{array}$ \\
\hline Sapindoideae Burnett Schleichereae Radlk. (Sch) & $\begin{array}{l}\text { Schleichera } \\
\text { Tinopsis } \\
\text { Tsingya }\end{array}$ & $\begin{array}{l}\text { Willd. } \\
\text { Radlk. } \\
\text { Capuron }\end{array}$ & & $\begin{array}{l}1 \\
11 \\
1\end{array}$ & $\begin{array}{l}\mathrm{t} \\
\mathrm{t} \\
\mathrm{t}\end{array}$ & $\begin{array}{l}\text { Tropical SE Asia to Indo-China and Malesia } \\
\text { Madagascar } \\
\text { Madagascar }\end{array}$ \\
\hline Thouinieae $\mathrm{Bl}$. (Tho) 6/6 genera, $10 / 285$ species & $\begin{array}{l}\text { Allophylus } \\
\text { Athyana } \\
\text { Bridgesia } \\
\text { Diatenopteryx } \\
\text { Guindilia } \\
\text { Thouinia }\end{array}$ & $\begin{array}{l}\text { L. } \\
\text { (Griseb.) Radlk. } \\
\text { Bertero ex Cambess. } \\
\text { Radlk. } \\
\text { Hook \& Arn. } \\
\text { Poit. }\end{array}$ & & $\begin{array}{l}\text { c. } 250 \\
1 \\
1 \\
2 \\
3 \\
28\end{array}$ & $\begin{array}{l}\text { s-st-l } \\
\text { t } \\
\text { s-st } \\
\text { t } \\
\text { s } \\
1\end{array}$ & $\begin{array}{l}\text { Pantropical } \\
\text { South America } \\
\text { Chile } \\
\text { South America } \\
\text { South America } \\
\text { Mexico and West Indies }\end{array}$ \\
\hline Sapindoideae unplaced taxa $2 / 2$ genera, $2 / 2$ species & $\begin{array}{l}\text { Delavaya } \\
\text { Ungnadia }\end{array}$ & $\begin{array}{l}\text { Franchet } \\
\text { Endl. }\end{array}$ & & $\begin{array}{l}1 \\
1\end{array}$ & s-st & $\begin{array}{l}\text { SW China and N Vietnam } \\
\text { S North America }\end{array}$ \\
\hline Xanthoceroideae Thorne \& Reveal $1 / 1$ genera, $1 / 1$ species & Xanthoceras & Bunge & & 1 & s-st & N-NE China and Korea \\
\hline
\end{tabular}

for family Sapindaceae. This was achieved by analysing two data sets based on the same taxa, but including different levels of missing data (i.e., different number of markers). While the inclusion of missing data was widely recognized as a major drawback in phylogenetic analyses during the early 90s (e.g., Huelsenbeck, 1991; Wiens and Reeder, 1995), recent simulations (Wiens, 1998, 2003, 2006) and empirical analyses (Bapteste et al., 2002; Driskell et al., 2004; Phillipe et al., 2004) have shown that taxa comprising high levels of missing data could be accurately placed in phylogenies. Moreover, adding incomplete taxa to a phylogenetic analysis was even shown to improve the accuracy of a given topology, e.g. by subdividing misleading long branches (Wiens, 2005). However, there is a strong heterogeneity in the ability of the different phylogenetic algorithms for managing data sets with substantial levels of missing data (Wiens, 2006), with maximum parsimony performing poorly compared to model-based algorithms such as maximum likelihood and Bayesian inference (Wiens, 2005, 2006).

\section{Material and methods}

\subsection{Taxon sampling}

Species names, voucher information, and GenBank accession numbers for all sequences are provided in the Appendix. The sampling strategy was designed to encompass the majority of subfamilies, tribes and genera of the family as recognized by the existing classifications of Radlkofer (1933), Müller and Leenhouts (1976) and Thorne (2007). Ingroup sampling comprised 152 specimens representing $60.3 \%$ of the generic diversity ( 85 of the 141 genera; 28 of the 57 missing genera in this analysis are monospecific; Table 1). The outgroup included Anacardiaceae (Sorindeia sp.; defined as outgroup in all analyses; Savolainen et al., 2000; Muellner et al., 2007) and Simaroubaceae (Harrisonia abyssinica). Silica-gel dried samples (Chase and Hills, 1991) were collected in the field by the authors and complemented with materials from the DNA banks of the Missouri Botanical Garden (St. Louis, USA), the Royal Botanic Gardens, Kew (London, UK) and the James Cook University (Cairns, Australia).

\subsection{DNA sequencing}

Samples from the collections of the Missouri Botanical Garden and field collected samples were extracted in the laboratory of Evolutionary Botany at the University of Neuchâtel (Switzerland) using the QIAGEN DNeasy plant kit (Qiagen, Hilden, Germany) and following the manufacturer's protocol. Samples from the collections of the Royal Botanic Gardens, Kew, were extracted using the $2 \times$ cetyltrimethylammonium bromide (CTAB) procedure of Doyle and Doyle (1987) with minor modifications (see Muellner et al., 2005) followed by additional purification using a caesium chloride/ethidium bromide gradient $(1.55 \mathrm{~g} / \mathrm{ml})$ and a dialysis procedure. The samples from James Cook University (Cairns, Australia) were extracted with the CTAB procedure of Doyle and Doyle (1987).

Seven plastid DNA regions and one nuclear ribosomal DNA region were amplified. Primers for the plastid regions are those described in Edwards and Gadek (2001) for matK (specific primer for the Dodonaeoideae were designed by Harrington et al., 2005) and the trnK-matK intergenic spacer (IGS), the DNA barcoding project (http://www.kew.org/barcoding/update.html) for $r p o B$, Demesure et al. (1995) for the trnD-trnT IGS, Taberlet et al. (1991) for trnL intron and trnL-trnF IGS, and Hamilton (1999) for trnS-trnG IGS. Primers for the ITS region are described in White et al. (1990) and additional primers were designed by Edwards and Gadek (2001) for Sapindaceae s.l.

Amplification of selected regions were achieved in a $25 \mu \mathrm{l}$ reaction mixture containing $5 \mu \mathrm{l} 5 \times$ PCR buffer, $1.5 \mu \mathrm{l} 25 \mathrm{mM} \mathrm{MgCl}_{2}$, $0.5 \mu \mathrm{l} 10 \mathrm{mM}$ dNTPs, $0.5 \mu \mathrm{l} 10 \mathrm{mM}$ primers, $0.2 \mu \mathrm{l}$ GoTaq polymer-

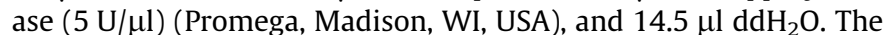
amplification of the matK region was improved by the addition of $4 \%$ DMSO in the total volume of the PCR mix. PCR was performed 
in a Biometra ${ }^{\circledR} \mathrm{T} 3$ thermocycler. Initial denaturation was programmed for $2 \mathrm{~min}$ at $95{ }^{\circ} \mathrm{C}$, followed by 35 cycles at $95^{\circ} \mathrm{C}$ for $45 \mathrm{~s}, 50^{\circ} \mathrm{C}$ for $45 \mathrm{~s}, 72{ }^{\circ} \mathrm{C}$ for $1 \mathrm{~min}$, plus a final extension of $10 \mathrm{~min}$ at $72^{\circ} \mathrm{C}$. PCR products were purified using the QIAquick PCR purification kit (Qiagen, Hilden, Germany) and fluorescent sequencing was performed by Macrogen, Inc. (Seoul, South Korea) with the same primers used for PCR amplification.

\subsection{Alignment}

The program Sequencher version 4.1 (Gene Codes Corp., Ann Arbor, Michigan, USA) was used to assemble complementary strands and verify software base-calling. The eight regions where initially aligned individually with ClustalX (Thompson et al., 1997), and thereafter manually adjusted with the program Bioedit (Hall, 1999) using the similarity criterion (Morrison, 2006). The program Concatenate (Alexis Criscuolo, http://www.lirmm.fr/ criscuol/) was used to construct two combined matrices, differing in the number of markers considered and in the level of missing data (see below).

\subsection{Phylogenetic analyses}

\subsubsection{Single-gene analyses}

Individual phylogenetic analyses and their corresponding bootstrap analyses were performed using the maximum likelihood (ML) and maximum parsimony (MP) criteria. Each partition and the combined data sets were analyzed using parsimony ratchet (Nixon, 1999) as implemented in PAUPrat (Sikes and Lewis, 2001). Based on recommendations by Nixon (1999), ten independent searches were performed with 200 iterations and $15 \%$ of the parsimony informative characters perturbed. The shortest equally most parsimonious trees were combined to produce a strict consensus tree. To assess the support at each node, non parametric bootstrap analyses (Felsenstein, 1985) were performed using PAUP* version 4.0b10 (Swofford, 2002) with 1000 replicates, SPR branch swapping, simple sequence addition, MULTREES and holding 10 trees per replicate. We used SPR branch swapping because it has been shown to be twice as fast as TBR and results in support percentages that are not significantly different (Salamin et al., 2003).

Model selection for each partition was assessed using Modeltest version 3.7 (Posada and Crandall, 1998) and the Akaike information criterion (Akaike, 1973). ML analyses were performed using RAxML version 7.0.0 (Stamatakis, 2006; Stamatakis et al., 2008) with a 1000 rapid bootstrap analyses followed by the search of the best-scoring ML tree in one single run. This analysis was done using the facilities offered by the CIPRES portal in San-Diego, USA (http://8ball.sdsc.edu:8888/cipres-web/home).

In this study, nodes with bootstrap supports (BS) below $50 \%$ are considered not supported, 50-74\% are considered weakly supported, $75-89 \%$ are moderately supported and $90-100 \%$ are strongly supported. Topological differences between single-gene phylogenetic trees were compared using Treejuxtaposer (Munzner et al., 2003), taking into account the level of resolution of each marker and their bootstrap supports. In this study, topological differences having a bootstrap support inferior to $75 \%$ were not considered.

\subsubsection{Combined analyses}

The impact of missing data on combined MP and ML phylogenetic analyses was tested based on two different combined matrices. The first matrix (hereafter named "4 markers" data set) was composed of specimens for which sequence information was available for the nuclear ribosomal ITS region and for three of the seven plastid regions (rpoB, trnL intron and trnL-trnF IGS).
In this combined matrix, the four remaining plastid markers were not included in order to have a complete matrix without missing data. The second combined matrix (hereafter named "4+4 markers" data set) comprised the same set of taxa as the "4 markers" data set, but also included the other four plastid markers (matK, trnD-trnT IGS, trnK-matK IGS and trnS-trnG IGS). This data set was designed to evaluate the effect of additional information on the resolution and support of topologies in comparison to the " 4 markers" analyses. Taxa for which no sequences were available for a given marker were coded as missing data for the corresponding cells in the combined matrix (sensu Wiens and Reeder, 1995).

Total evidence trees (sensu Kluge, 1989) were determined using both ML and MP criteria on the two data sets using the same settings as in the single-gene analyses. Non parametric bootstrap analyses were performed for the data sets following the same settings as for the single-gene analyses. Before computing total evidence trees, an incongruence length difference (ILD) test (Farris et al., 1994) was performed as implemented in PAUP* version $4.0 \mathrm{~b} 10$ (Swofford, 2002) with 100 replicates.

\subsection{Topological congruence and impact of missing data on combined analyses}

Based on analyses of the combined matrices (i.e., " 4 markers" and "4+4 markers" data sets), the impact of missing data on MP and ML phylogenetic analyses was investigated (i) by assessing topological distances among trees obtained using different data sets and algorithms and (ii) by comparing taxa groupings (and clade supports) in each topology. The explicitly agree distance (Estabrook et al., 1985; Estabrook, 1992; EA distance) was calculated to evaluate the extent to which total evidence trees were compatible with each other. The EA distance quantifies the differences between trees of the same size (i.e., comprising the same number of terminal taxa). It evaluates the proportion of triplets that are resolved identically in two trees (see Wilkinson et al., 2005). EA distances were calculated using DARWIN 5 (Perrier et al., 2003). The congruence of topological groupings in analyses obtained from different data sets and algorithms was evaluated using Treejuxtaposer (Munzner et al., 2003) and bootstrap supports of each main clade were compared.

\section{Results}

\subsection{Alignment}

The number of sequences included in each single-gene partition varied from 69 in trnS-trnG IGS to 154 in rpoB, trnL intron and trnL-trnF IGS (Table 2). For the ITS region, all specimens were sequenced, except the outgroup species Sorindeia sp. (i.e., 153 sequences were produced). The alignment length ranged from $363 \mathrm{bp}$ in $r p o B$ to $2156 \mathrm{bp}$ in trnS-trnG IGS (Table 2). The ITS region had the highest number of variable characters (51.4\%), whereas trnS-trnG IGS had the lowest (23.8\%), even less than the coding regions matK and $r p o B$ (29.1\% and $37.2 \%$, respectively). The same trend was recorded for the percentage of potentially parsimonyinformative characters (37.8\% for the ITS region and $9.0 \%$ for the trnS-trnG IGS; Table 2).

The combined data sets consisted respectively of 615 sequences (154 specimens; no missing data in ingroup taxa) for the "4 markers" data set, and 997 sequences (154 specimens; $18.6 \%$ missing data) for the " $4+4$ markers" data set (Table 2 ). The alignment length of the two data sets was respectively 3031 bp ("4 markers") and 9657 bp ("4+4 markers"). The "4 
markers" data set had a highest percentage of variable characters (44.7\%) than the " $4+4$ markers" data set $(37.0 \%)$. The same observations were recorded for the percentage of potentially parsimony-informative characters $(30.3 \%$ for the " 4 markers" and $21.2 \%$ for the " $4+4$ markers" data sets; Table 2 ). However, when considering the total amount of phylogenetic information averaged by the number of taxa, the " $4+4$ markers" data set showed a value more than twice higher than did the " 4 markers" data set (Table 2).

\subsection{Phylogenetic analyses}

\subsubsection{Single-gene analyses}

The best-fit model for all partitions was the general time reversible (GTR) with an alpha parameter for the shape of the gamma distribution to account for among-site rate heterogeneity (Yang, 1993). The only exception was for the ITS region for which a proportion of invariable sites was added. Although the MP and ML single-gene analyses provided topologies with different levels of resolution within Sapindaceae s.l. (e.g., the MP trees were usually not resolved in several parts of the tree), no moderately to strongly supported differences ( $>75 \%$ ) were observed between single-gene trees. In addition, the ILD test was not significant $(P=0.9)$ and indicated that the eight data sets were congruent. Those results allowed the combination of the partitions in a total evidence approach. Statistics (number of most parsimonious trees; tree length; consistency and retention indices) for each analysis are reported in Table 2 .

\subsubsection{Combined analyses}

The most parsimonious trees for the two combined analyses under the MP criterion were respectively 5889 ("4 markers" data set) and 9843 ("4+4 markers" data set) steps. Under the ML criterion, the best-fit model for the combined matrices was GTR with a proportion of invariable sites and an alpha parameter for the shape of the gamma distribution to account for among-site rate heterogeneity (Yang, 1993). This model was used to perform the ML search (log likelihoods were -34322.2 for the " 4 markers" data set and -69253.8 for the " $4+4$ markers" data set) followed by rapid bootstrap analyses.

\subsection{Topological congruence and impact of missing data on combined analyses}

The congruence (expressed by 1 - EA distance) between total evidence trees compiled under the ML criterion was higher (98\% of common triplets between total evidence trees based on " 4 markers" and " $4+4$ markers" data sets) than between total evidence trees obtained under MP criterion ( $90 \%$ of common triplets between total evidence trees based on " 4 markers" and " $4+4$ markers" data sets) (Table 3 ). The MP " 4 markers" total evidence tree exhibits the highest EA distances with the other total evidence trees (Table 3).

Each of the four total evidence analyses showed support for the monophyly of Sapindaceae s.l. as defined by Thorne (2007) including Aceraceae and Hippocastanaceae (Table 4). No matter which data set or algorithm were considered, the family was subdivided into three moderately to strongly-supported lineages and a fourth lineage only consisting of Xanthoceras sorbifolia, with the following relationships: (Xanthoceras sorbifolia, (clade A, (clade B, clade C))) (Table 4, Fig. 2). Despite strong support for each clade, the sister position of the monotypic Xanthoceras was not supported in any analyses (see clade A + clade B + clade $C$ in Table 4). This lineage corresponded to subfamily Xanthoceroideae as described by Thorne (2007). Clade A corresponded to

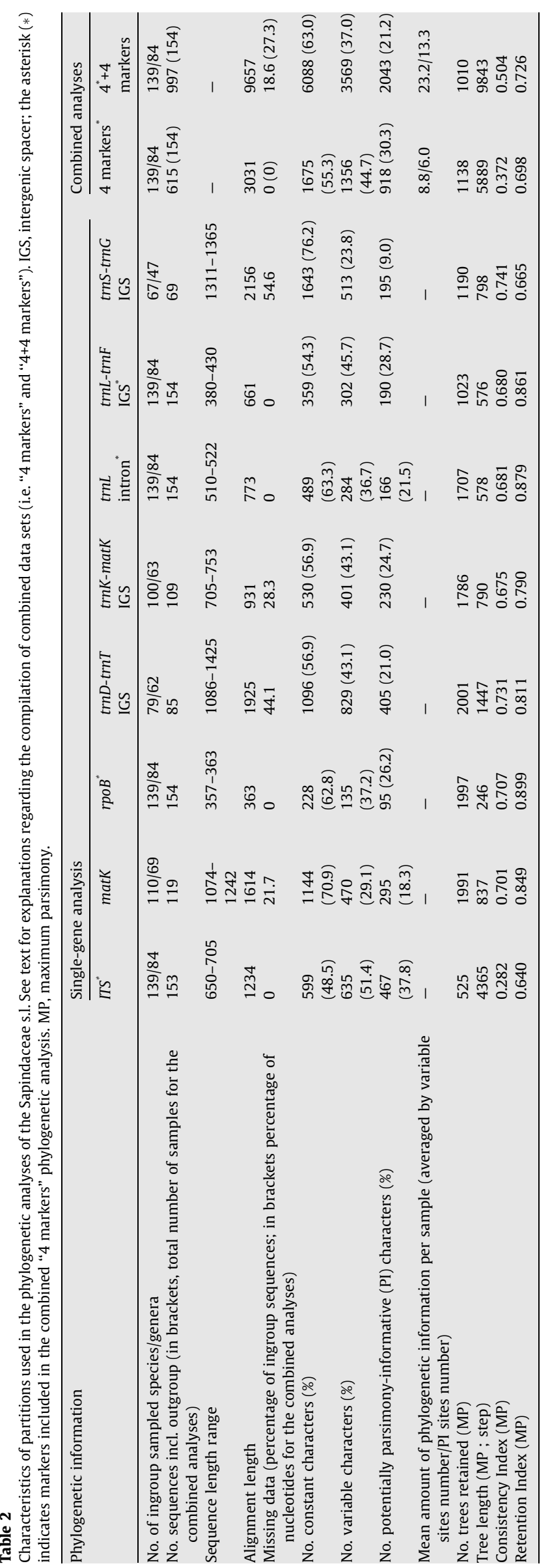


Table 3

Level of topological agreement (based on EA distances) between total evidence trees inferred from the " 4 markers" and "4+4 markers" data sets. See text for explanations regarding the compilation of these data sets. MP, maximum parsimony; ML, maximum likelihood.

\begin{tabular}{lllll}
\hline & 1 & 2 & 3 & 4 \\
\hline 1- ML “4 markers” & - & & & \\
2- MP “4 markers” & 0.177 & - & & \\
3- ML “4+4 markers” & 0.021 & 0.189 & - & - \\
4- MP “4+4 markers” & 0.028 & 0.173 & 0.027 & - \\
\hline
\end{tabular}

subfamily Hippocastanoideae (including the previous recognized families Aceraceae and Hippocastanaceae) as described by Harrington et al. (2005) and Thorne (2007). Clade B corresponded to subfamily Dodonaeoideae as described by Harrington et al. (2005) and Thorne (2007) with the addition of Euphorianthus (Cupanieae; Sapindoideae). Clade C corresponded to subfamily Sapindoideae (Thorne, 2007; Harrington et al., 2005) plus one representative from Dodonaeoideae, Conchopetalum, included in tribe Harpullieae. Clade $C$ was moderately to strongly supported as monophyletic and divided into ten groups, but not in the MP "4 markers" total evidence tree (only one exception: clade V nested in clade VI; Table 4). The bootstrap supports of each clade obtained under the ML algorithm are consistent in both data sets (Table 4), whereas support slightly increases in MP analyses, in parallel to an increase in missing data (Table 4).

The " 4 markers" and " $4+4$ markers" topologies recognized all the classical tribes (except the Paullinieae) as paraphyletic or polyphyletic. However, phylogenetic status of tribes Cossinieae and Koelreuterieae were not tested because only one genus per tribe was considered. In total 5 of the 67 non-monotypic sampled genera $(7.5 \%)$ are paraphyletic or polyphyletic (Cupaniopsis, Guioa, Haplocoelum, Matayba, Sarcotoechia). However, the phylogenetic status of some of these genera needs to be treated with caution because of weak bootstrap supports and limited sampling (e.g., Guioa).

\section{Discussion}

\subsection{Congruence of topologies with and without missing data}

Our results indicate a high level of congruence among topologies obtained using data sets with and without missing data and based on different algorithms. Considering the " 4 markers" data set (without missing data), MP and ML algorithms however produced slightly different topologies regarding clades $\mathrm{C}-\mathrm{V}$ and C-VI (i.e., in the MP " 4 markers" tree clade C-VI is paraphyletic with the inclusion of the clade $\mathrm{C}-\mathrm{V}$, whereas all other topologies considered this clade as monophyletic; Table 4). This could be explained mostly by the small amount of phylogenetic information in the "4 markers" data set that prevent the MP algorithm to find a proper solution (averaged over the number of terminal taxa; Table 2). Although the addition of 4 markers to the data set generated $18.6 \%$ of missing data $(27.3 \%$ of missing nucleotides) in the " $4+4$ markers" data set, the added information doubled the mean amount of potentially parsimonious-informative characters per terminal taxa and increased the bootstrap support for several nodes in the total evidence trees (Tables 2 and 4). Since our results highlight a high congruence level among topologies obtained with different data sets and algorithms, only the ML total evidence tree inferred from the " $4+4$ markers" data set will be discussed in order to maximize phylogenetic information (Figs. 2-6).

\subsection{Phylogenetic relationships}

Our results support (1) the paraphyly of the currently defined Dodonaeoideae and Sapindoideae as defined by Thorne (2007); (2) the polyphyly of all tribes (tribes Cossinieae and Koelreuterieae are not considered because only one genus per tribe was sampled) with the possible exception of Paullinieae - whose monophyletic status shall be evaluated by the inclusion of three missing genera Houssayanthus, Lophostigma and Thinouia in future analyses - and (3) the paraphyly or polyphyly of 5 of the 67 non-monotypic sampled genera (7.5\%) included in this study (Table 1 ).

Table 4

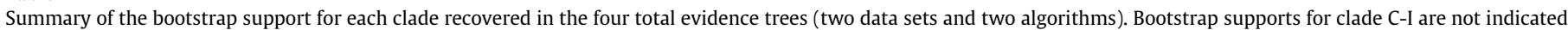

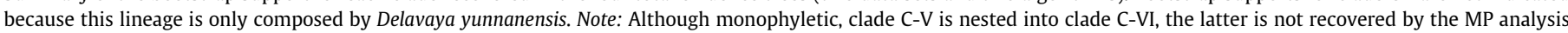
based on the " 4 markers" data set. MP, maximum parsimony; ML, maximum likelihood.

\begin{tabular}{|c|c|c|c|c|}
\hline \multirow[t]{2}{*}{ Combined data sets } & \multicolumn{2}{|l|}{ ML } & \multicolumn{2}{|l|}{ MP } \\
\hline & 4 markers & $4+4$ markers & 4 markers & $4+4$ markers \\
\hline Sapindaceae s.l. & 94 & 91 & 97 & 97 \\
\hline Clade $\mathrm{A}+$ Clade $\mathrm{B}+$ Clade $\mathrm{C}$ & 65 & 58 & 60 & 57 \\
\hline Clade A & 100 & 100 & 99 & 99 \\
\hline Clade B & 94 & 91 & 99 & 99 \\
\hline B-I & 100 & 100 & 100 & 100 \\
\hline B-II & 88 & 77 & 86 & 86 \\
\hline Clade C & 92 & 87 & 96 & 98 \\
\hline C-II & 100 & 100 & 100 & 100 \\
\hline C-III & 100 & 100 & 100 & 100 \\
\hline C-IV & 77 & 98 & $<50$ & 65 \\
\hline C-IV-a & 73 & 100 & 73 & 100 \\
\hline C-IV-b & 100 & 100 & $<50$ & 83 \\
\hline $\mathrm{C}-\mathrm{V}$ & 100 & 100 & 99 & 100 \\
\hline C-VI & 60 & 75 & - & $<50$ \\
\hline C-VI-a & 69 & 89 & $<50$ & 65 \\
\hline C-VI-b & 65 & 83 & $<50$ & 58 \\
\hline C-VII & 100 & 100 & 100 & 100 \\
\hline C-VIII & 60 & 61 & 50 & 70 \\
\hline C-IX & 100 & 100 & 99 & 100 \\
\hline$C-X$ & 100 & 100 & 93 & 100 \\
\hline
\end{tabular}




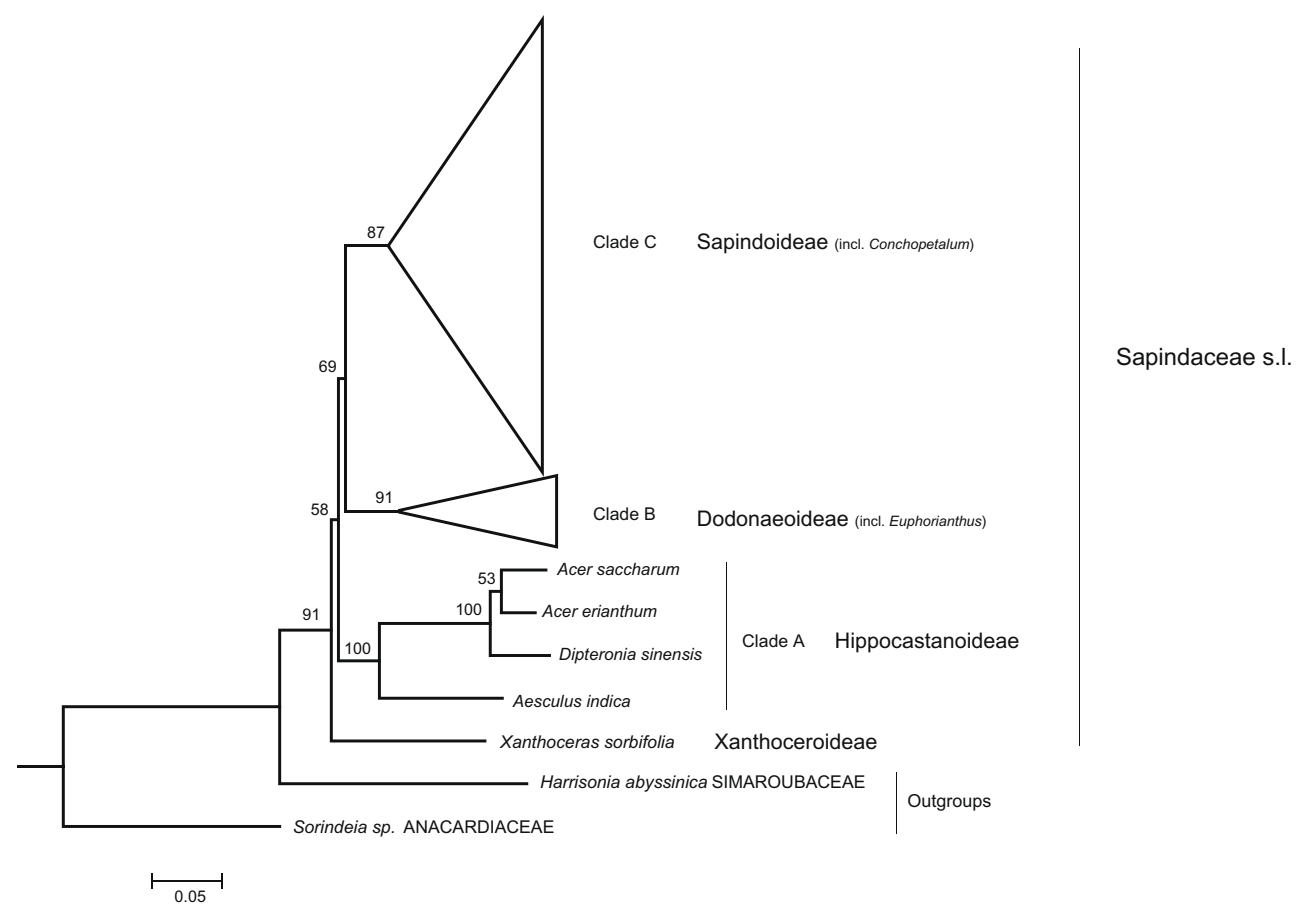

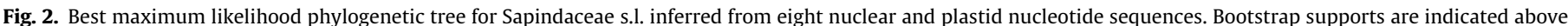

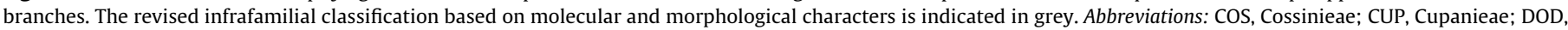

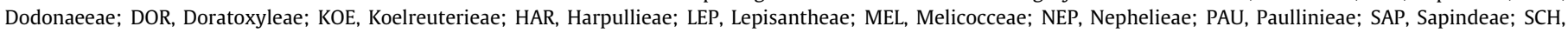
Schleichereae; THO, Thouinieae.

In light of these results, a new infrafamilial classification for Sapindaceae s.l. is required. However, we recommend caution in formally proposing new tribes until (i) non-molecular synapomorphies supporting putative new tribal delimitations are identified and (ii) the inclusion of missing genera in future phylogenetic analyses. In order to provide efficient guidelines for a new classification of the family, the phylogenetic framework obtained here is discussed according to several key morphological characters such as leaf type (including phyllotaxy), wood anatomy, number of ovules per locule, fruit type and pollen (Fig. 1), as well as geographical distribution. Hereafter, the definition of Dodonaeoideae and Sapindoideae will be expanded to include Euphorianthus in the former and Conchopetalum in the latter.

Xanthoceroideae and Hippocastanoideae occur mostly in temperate regions [except Billia (not included here), which occurs from Mexico to tropical South America], whereas Dodonaeoideae have a temperate (e.g., south of Australia) and tropical pattern of distribution. On the other hand, Sapindoideae have mainly radiated in tropical regions. Within Sapindaceae s.l., a trend towards the reduction of the number of ovule per locule is observed: from six to eight (Xanthoceroideae) to two (Hippocastanoideae and most of the Dodonaeoideae) and finally one (Sapindoideae except Conchopetalum). All four subfamilies recognized by Thorne (2007) are discussed separately below.

\subsection{Subfamily Xanthoceroideae (Fig. 2)}

The phylogenetic position of the monotypic Chinese Xanthoceras in relation to the other three main lineages of Sapindaceae remains unsupported (BS < 50) (Fig. 2; Table 4). Nevertheless, this species was moderately supported as the earliest-diverging lineage in Sapindaceae s.l. in earlier studies (matK, $r b c L$, Harrington et al., 2005; rbcL, Savolainen et al., 2000; 18S rDNA, atpB, rbcL, Soltis et al., 2000). In the first molecular phylogeny of Sapindaceae s.l., Harrington et al. (2005) argued that an increased sampling of other monotypic Southeast Asian genera of Harpullieae (e.g., Arfeuillea, Delavaya, Eurycorymbus) and Koelreuterieae (Sinoradlkofera) might help break up possible long-branch attraction and stabilize the position of this taxon. However, our study shows that even when considering $60.3 \%$ of the generic diversity and including Arfeuillea, Delavaya and Eurycorymbus, the phylogenetic position of this genus remains unchanged. This small shrub is characterized by unusual features in Sapindaceae such as deciduous imparipinnate leaves (vs. deciduous simple leaves or sempervirent imparipinnate or paripinnate leaves in other Sapindaceae), six to eight fertile ovules per locule (generally 1 or 2 ovules per locule in the rest of the family) and the presence of orange horn-like appendages protruding from the disk (absent in other genera). Moreover, this species exhibits a type-A pollen which was expected to be ancestral in Sapindaceae by Müller and Leenhouts (1976) (Fig. 1). However, this pollen type is widespread across the taxa sampled in our phylogeny and is consequently of limited systematic utility.

\subsection{Subfamily Hippocastanoideae (Clade A, Fig. 2)}

The inclusion of Aceraceae and Hippocastanaceae in Sapindaceae has been debated for decades (e.g., Radlkofer, 1933; Müller and Leenhouts, 1976; Umadevi and Daniel, 1991; Judd et al., 1994) and both are currently included in Sapindaceae by the Angiosperm Phylogeny Group (APGII, 2003). However, the final decision regarding the taxonomic level of this well-supported clade (BS 100, Fig. 2) is somewhat dependant on the placement of Xanthoceras sorbifolia. Although Billia and Handeliodendron, thought to be close relative of Aesculus (Xiang et al., 1998; Forest et al., 2001), were not sampled here, the analysis confirms the definition of Hippocastanoideae as previously suggested by Judd et al. (1994) and Harrington et al. (2005). This temperate clade is charac- 


\section{Clade B}

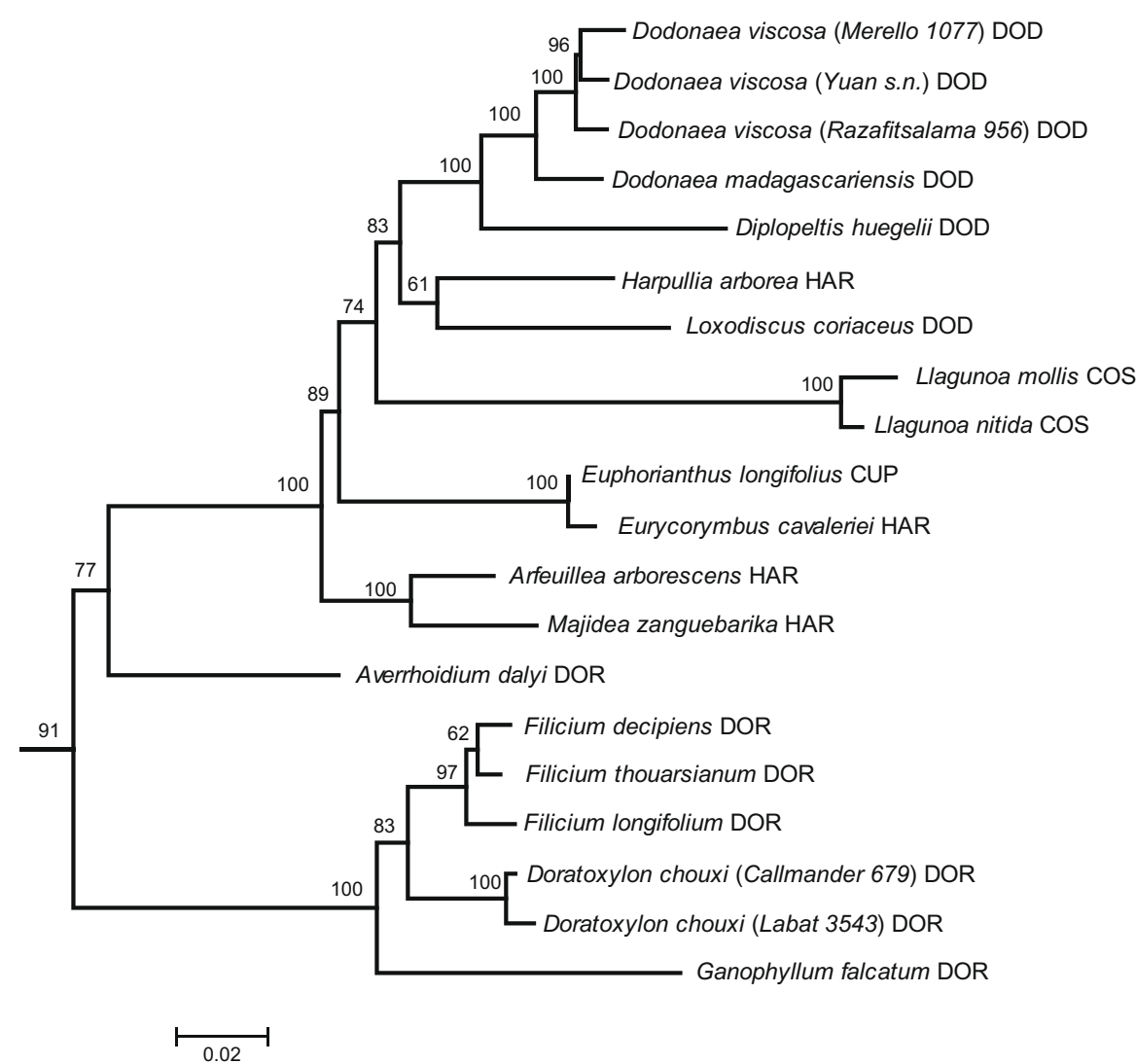

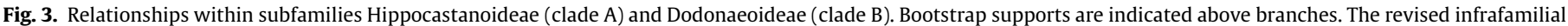
classification based on molecular and morphological characters is indicated in grey. See Fig. 2 for abbreviations of tribes.

terized by deciduous opposite simple leaves (generally palmatilobate), two ovules per locule and a type-A pollen (Biesboer, 1975; Müller and Leenhouts, 1976, Fig. 1).

\subsection{Subfamily Dodonaeoideae (Clade B, Figs. 2 and 3)}

The improved sampling for subfamily Dodonaeoideae (i.e., the addition of genera Arfeuillea, Averrhoidium, Doratoxylon, Euphorianthus, Eurycorymbus, Llagunoa and Majidea) allows the recognition of two moderately to well-supported clades (Fig. 3, Table 4). This topology was partially recovered by Harrington et al. (2005), but the addition of new taxa allow their delimitation based on fruit morphology: clade I (Doratoxylon group) occurs from Africa, Madagascar to Australasia and is characterized by indehiscent berrylike fruits, whereas clade II (Dodonaea group) is distributed in South America, Madagascar, Australasia and the Pacific islands (Dodonaea viscosa had a worldwide distribution) and comprises species with dehiscent fruits. In addition to the widespread type-A pollen occurring in both clades, specialized pollen types characterizing specific taxa occur in clade II [i.e., type-F (Diplopeltis hueglii) and type-H (Harpullia cupanoides)] (George and Erdtman, 1969; Müller and Leenhouts, 1976, Fig. 1). Clades I and II have generally two ovules per locule; however a reduction to one ovule per locule occurs independently in the two clades (Filicium in clade I and Euphorianthus in clade II). Moreover, a few species of Harpullia (clade II), such as $H$. arborea, have 1-2 ovules per locule (Adema et al., 1994).

\subsection{Subfamily Sapindoideae (clade C, Figs. 2 and 4-6)}

\subsubsection{Early-diverging lineages (Fig. 4)}

Subfamily Sapindoideae is by far the most diverse lineage in terms of species. Based on our analyses, we propose to divide it into ten groups that are discussed in light of their morphological features, geographical distribution and compared to tree topologies obtained by Harrington et al. (2005) (Figs. 4-6). The Delavaya group is the first lineage to diverge in Sapindoideae (clade I). Only the Chinese monotypic genus Delavaya is included in the present study. Results from Harrington et al. (2005) highlighted the Mexican and Texan genus Ungnadia (from which nuclear sequences were unavailable) as the most basal lineage in Sapindoideae. Combined plastid analyses (Buerki, unpublished data) revealed a closerelationship between those two genera as suggested by Judd et al. (1994; based on morphological characters); however this relationship must be further examined using nuclear sequences. The Delavaya group is characterized by elongated petal base appendages and glabrous stamens (Judd et al., 1994) and the wood anatomy within the group is identical to the Cupanieae (Klaassen, 1999). The Koelreuteria group (clade II, BS 100), here comprising only Koelreuteria, is distributed in southern China and western Pacific. The study of Harrington et al. (2005) revealed a close-relationship between this genus and Smellophylum and Stadmania, distributed in East-Africa, Madagascar and the Mascarene archipelago. When a broad definition is considered, the Koelreuteria group shows both ancestral (type-A pollen; Müller and Leenhouts, 1976, Fig. 1) and 


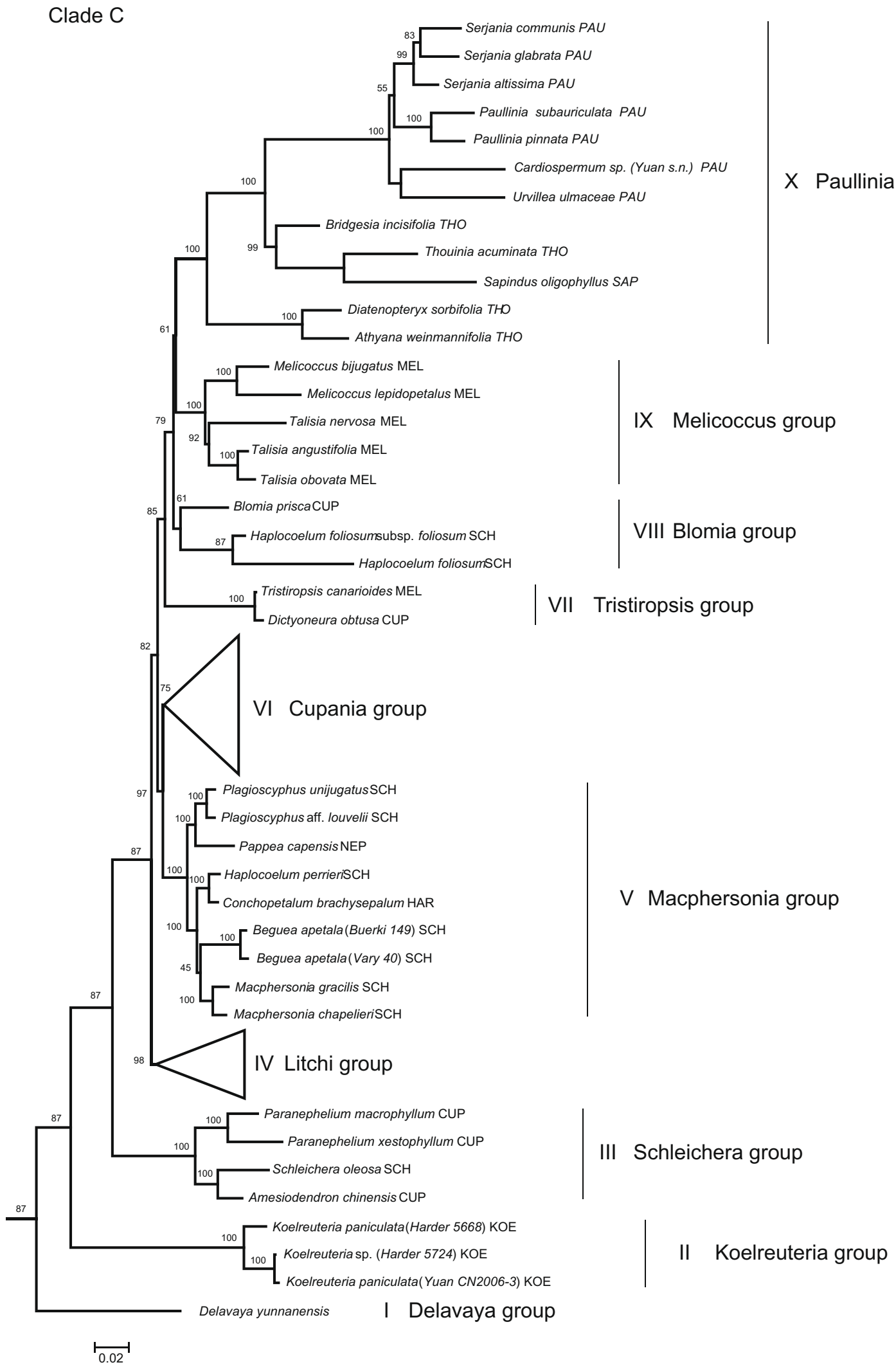

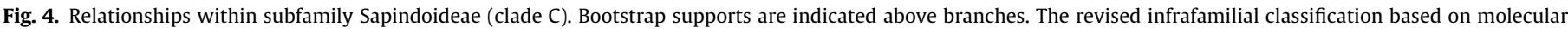
and morphological characters is in grey. See Fig. 2 for abbreviations of tribes.

derived characters (one ovule per locule in Smellophylum and Stadmania) and is characterized by the presence of trichomes on the anther. Since these two lineages show a disjunct distribution and transitional character states, they might be relicts of early diversification events in the subfamily (caused by long distance dispersals for example). The Schleichera group, which is partially recovered by 


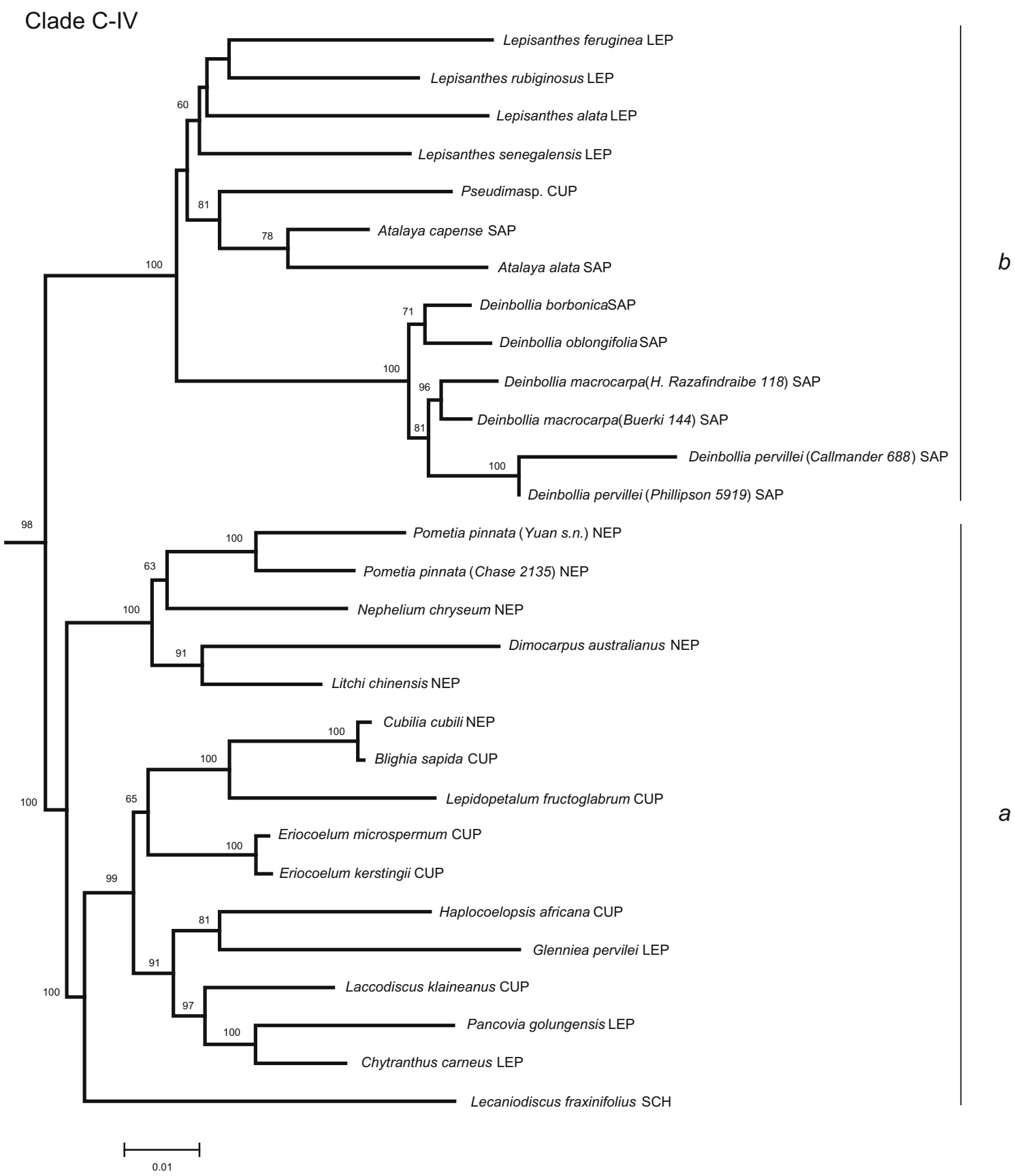

Fig. 5. Phylogenetic relationships within the Litchi group (clade C-IV; see Fig. 4). Bootstrap supports are indicated above branches. See Fig. 2 for abbreviations of tribes.

Harrington et al. (2005), here with the inclusion of Amesiodendron (Cupanieae), is a well-supported (BS 100) tropical Asian clade (clade III, Fig. 4). This clade is characterized by a Cupanieae-like wood anatomy (Klaassen, 1999) and type-B pollen (Müller and Leenhouts, 1976, Fig. 1).

\subsubsection{The Litchi group (Figs. 4 and 5)}

This clade (clade IV, BS 98, Fig. 4) is divided into two well-supported groups ( $a$ and $b$; Fig. 5). Clade $a$ (BS 100) partially corresponds to the Dimocarpus group proposed by Müller and Leenhouts (1976; traditionally comprising Cubilia, Dimocarpus, Litchi, Nephelium, Pometia and Xerospermum) and a heterogeneous group comprising mostly African genera as well as the Indian and Australian Lepidopetalum. Our study also confirms the close rela- tionships of Pometia (characterized by type-C1 pollen; Müller and Leenhouts, 1976; van der Ham, 1990, Fig. 1) with the other member of the Dimocarpus group as expected by Müller and Leenhouts (1976). The Lepisantheae-type wood anatomy of Eriocoelum (Cupanieae; Klaassen, 1999) confirms its relationships with the other genera of Lepisantheae from this clade. A more comprehensive analysis of this clade is currently being undertaken (Buerki, unpublished data).

Clade $b$ (BS 100) partially corresponds to group A of Müller and Leenhouts (1976) with the addition of Pseudima (Cupanieae). The inclusion of the South American Pseudima is supported by type-A pollen (Müller and Leenhouts, 1976, Fig. 1) and similar wood anatomy shared with other Sapindeae (Klaassen, 1999). Our results highlight the close affinities of Lepisanthes, Sapindus and Atalaya, 


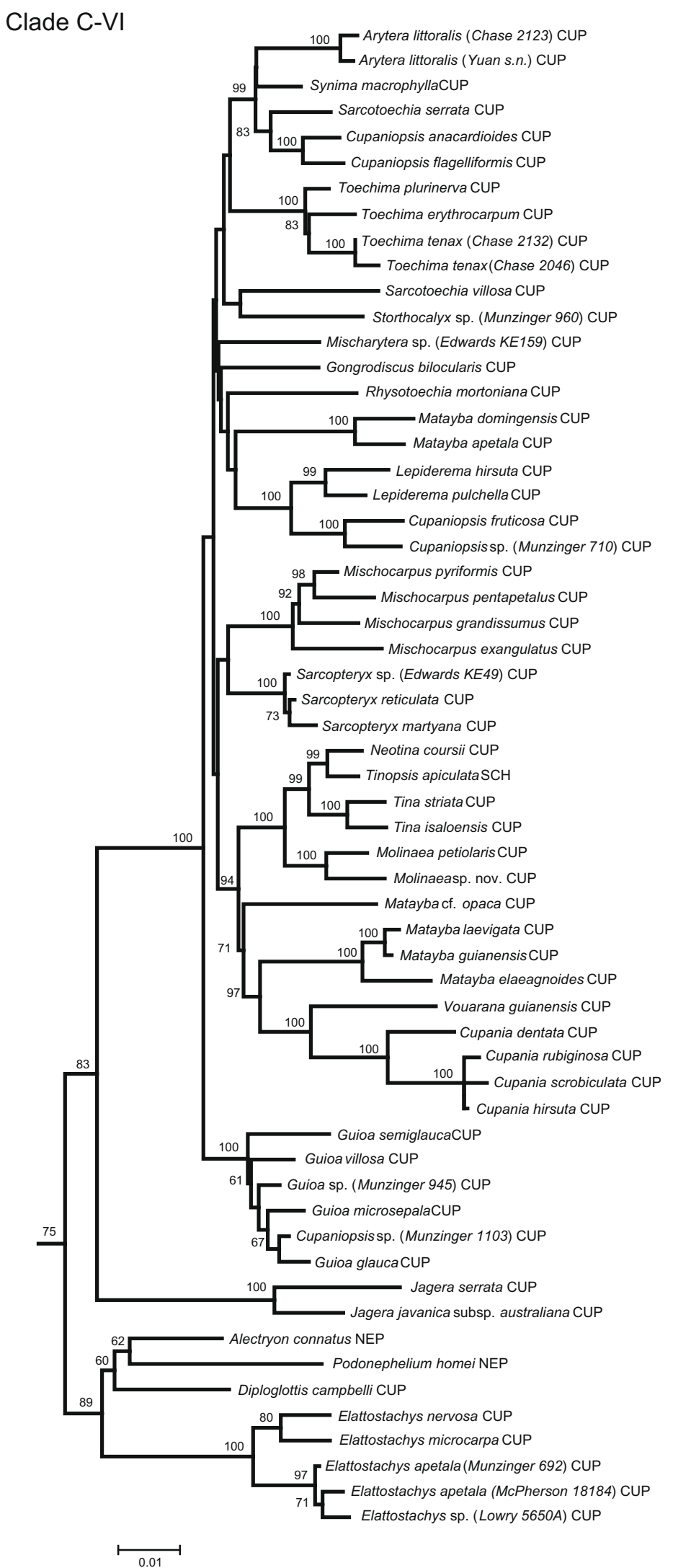

Fig. 6. Phylogenetic relationships within the Cupania group (clade C-VI; see Fig. 4). Bootstrap supports are indicated above branches. See Fig. 2 for abbreviations of tribes. 
but the understanding of relationships within this group will require additional data. The monophyly of the African-Malagasy Deinbollia is supported by molecular analyses and type-A1 pollen (Müller and Leenhouts, 1976, Fig. 1).

\subsubsection{The Macphersonia group (Fig. 4)}

Our study reveals for the first time relationships between southeast African and Malagasy genera (BS 100, Fig. 4). Two strongly supported clades were formed by South African Pappea capensis and Malagasy Plagioscyphus (BS 100) and Malagasy Beguea, Conchopetalum and Haplocoelum perrieri, as well as east African and Malagasy Macphersonia (BS 100). Pappea was previously thought to be related to other Nephelieae (Alectryon, Podonephelium, Smelophyllum and Stadmania) by Müller and Leenhouts (1976), and placed without support as sister to Paullinieae and Thouinieae by Harrington et al. (2005). The position of Conchopetalum, characterized by inflated fruits without arillode, in the traditional core Malagasy Schleichereae, defined by indehiscent fruits and a fleshy arillode surrounding the seed, was an unexpected result (Capuron, 1969). This clade is characterized by actinomorphic flowers, one ovule per locule (except two in Conchopetalum) and is distributed throughout Madagascar and southeast Africa.

\subsubsection{The Cupania group (Figs. 4 and 6)}

The Australasian and Malagasy/South American clade VI (BS 75 , Fig. 4) encloses the majority of Cupanieae genera (23 of the 32 sampled genera) and is divided into two main groups (Figs. 4 and 6). In the Australasian clade $a$ (BS 100), the monophyly of Elattostachys is well supported and the expected close relationship between the New Caledonian Podonephelium and Australasian and Pacific Alectryon is confirmed by this phylogenetic analysis and the shared type-A pollen (Müller and Leenhouts, 1976, Fig. 1). Only one non Cupanieae taxon belongs to clade $b$ (BS 100): Tinopsis apiculata (Schleichereae). The Malagasy Tinopsis was first described as part of the Cupanieae (Radlkofer, 1933) and later transferred to the Schleichereae based on the indehiscence of the fruit and the presence of a fleshy arillode (Capuron, 1969). However, no floral or vegetative characters have been identified to discriminate this genus from the Malagasy Cupanieae genera Tina and Neotina. This study confirms the close relationships between these genera and supports Radlkofer's (1933) hypothesis. This example and others encountered in clades II and V provide strong arguments supporting the convergent evolution of fruit morphology and consequently its limited systematic utility. The plasticity of fruit types has been demonstrated in several phylogenetic studies performed on a wide range of taxa (e.g., van Welzen, 1990; Adema, 1991; Muellner et al., 2003). The Cupania group is characterized by type-B pollen (except Alectryon and Podonephelium which have type-A pollen; Müller and Leenhouts, 1976, Fig. 1). In general, taxa within clade $b$ present low genetic distances among them while having long terminal branches (especially the Australasian representatives such as Cupaniopsis, Gongrodiscus and Toechima).

\subsubsection{The Paullinia group and allies (Tristiropsis, Blomia and Melicoccus groups) (Fig. 4)}

Although strongly supported in general (except for the Blomia group; Table 4), the relationships between these four groups remain unclear (Fig. 4). The monophyly of the Australasian clade VII and the Mexico/East African clade VIII are weakly to well-supported (BS 100 and BS 61, respectively, Fig. 4). To date, no morphological characters have been identified that circumscribe these lineages. The monophyly of the South American clade IX is well supported (BS 100, Fig. 4) and confirms the suggested affinities between Melicoccus and
Talisia argued by Acevedo-Rodríguez (2003) based on morphology and pollen characters.

The pantropical clade X (Fig. 4) is strongly supported (BS 100) and corresponds both to the Nomophyllae group defined by Radlkofer (1933) and to the group C proposed by Müller and Leenhouts (1976) containing Paullinieae and Thouinieae. Although no representatives of genus Allophylus (Thouinieae) were included here, our study confirms the results of the morphological cladistic analyses of the two tribes conducted by Acevedo-Rodríguez (1993b) and the molecular analyses of Harrington et al. (2005), which show a monophyletic Paullinieae nested in a paraphyletic Thouinieae. Our analysis indicates that the enigmatic species Sapindus oligophyllus has affinities with genera in this clade (Fig. 7). The generic position of this taxon has puzzled taxonomists for decades. It was first described as a member of Aphania and subsequently transferred in Sapindopsis, Howethoa, Sapindus (see Rauschert, 1982 for review) and recently merged, although informally, in Lepisanthes by Xia and Gadek (2007). The increase of sampling and the inclusion of Allophylus species might help to circumscribe the position of this taxon. Type-A pollen and the tree life-form are shared by the most basal lineages in this clade (Athyana weinmannifolia, Diatenopteryx sorbifolia and Bridgesia incisifolia; Acevedo-Rodríguez, 1993b, Figs. 1 and 7), whereas the other taxa have a highly specialized pollen type (type-C2-3; Müller and Leenhouts, 1976, Fig. 1) and a tendency towards liana habit. Species with subtype$\mathrm{C}$ pollen do not form a monophyletic group and consequently this character is of limited systematic value (e.g., type-C3 is encountered in Thouinia and Paullinia; Müller and Leenhouts, 1976; Acevedo-Rodríguez, 1993b, Figs. 1 and 4). Clade X is characterized by zygomorphic flowers, petals with a prominent scale, an unilateral disk and imparipinnate leaves. The liana habit and the development of tendrils and stipules constitute synapomorphies for Paullinieae (Fig. 4).

\subsection{Informal tribal groupings within Sapindaceae}

The phylogenetic analysis inferred from eight nuclear and plastid regions provides a robust assessment of the relationships within Sapindaceae s.l. (although the relationships between the subfamilies remain weakly supported) (Fig. 2). Nevertheless, the tribal delimitations as currently defined (and based largely on fruit morphology) must be revised because of the plasticity of fruit characters in this group. When Richardson et al. (2000a,b) assessed the tribal classification of Rhamnaceae (also defined by fruit morphology), they encountered the same taxonomic difficulty and proposed a new classification based on molecular data in combination with morphological characters. We follow a similar approach and propose here an informal grouping that could serve as basis for a formal reclassification of Sapindaceae s.l. based on molecular and morphological data. The family is subdivided into four subfamilies (as recognized by Thorne, 2007) and 14 groups: Xanthoceroideae, Hippocastanoideae (two groups); Dodonaeoideae (two groups) and Sapindoideae (10 groups) (Figs. 2-4). The groups within subfamilies might represent circumscriptions for the definition of future tribes.

\subsubsection{Subfamily Xanthoceroideae}

It includes the monotypic Chinese Xanthoceras sorbifolia, this deciduous shrub is characterized by alternate imparipinnate leaves, $6-8$ ovules per locule and orange horn-like appendages protruding from the disk (Fig. 2).

\subsubsection{Subfamily Hippocastanoideae}

Temperate deciduous shrubs and trees (except Billia found from Mexico to tropical South America) with simple generally 
palmatilobate opposite leaves and 2 ovules per locule (Fig. 2). Although our sampling is limited for this subfamily, results from other studies (Judd et al., 1994; Harrington et al., 2005; Buerki, unpublished data) allows us to suggest two groups within subfamily Hippocastanoideae, corresponding to the formerly recognized families Aceraceae and Hippocastanaceae (Fig. 4):

- Acer group (Acer and Dipteronia): leaves palmately lobed to 3foliate or imparipinnate, or entire; actinomorphic unisexual or bisexual flowers and samara;

- Aesculus group (Aesculus, Billia and Handeliodendron): leaves palmately divided into 3-5 leaflets; zygomorphic andromonoecious flowers and dehiscent fruit with one seed.

\subsubsection{Subfamily Dodonaeoideae}

This subfamily is expanded to include Euphorianthus, formerly placed in Sapindoideae. The Dodonaeoideae as defined by Radlkofer $(1890,1933)$ are characterized by the presence of two or rarely more apotropous and upright ovules per locule, or rarely one ovule that is epitropous and pendulous. However, this does not hold anymore because of the inclusion of the above mentioned genus of Sapindoideae showing one campylotropous ovule per locule. This subfamily is divided into two groups (Fig. 3):

- Doratoxylon group (Doratoxyleae, without Averrhoidium): indehiscent berry-like fruits;

- Dodonaea group (Cossinieae, Dodonaeeae, Arfeuillea, Averrhoidium, Eurycorymbus, Euphorianthus, Harpullia and Majidea): dehiscent fruits.

\subsubsection{Subfamily Sapindoideae}

The subfamily Sapindoideae should be expanded to include Conchopetalum, formerly placed into the Dodonaeoideae. This subfamily as defined by Radlkofer (1933) is characterized by a single apotropous and upright or ascending ovule per locule; however the inclusion of several genera with two ovules per locule [Conchopetalum (this study), Delavaya, Koelreuteria and Ungnadia; Harrington et al., 2005; Thorne, 2007; this study] renders this key-character obsolete. Based on our phylogenetic analysis, ten groups are now recognized (Fig. 4):

- Delavaya group (Delavaya and Ungnadia): two ovules per locule; type-A pollen; elongated basal petals appendages; glabrous stamens and Cupanieae wood anatomy.

- Koelreuteria group (Koelreuteria, Smelophyllum and Stadmania): type-A pollen and trichomes on anthers.

- Schleichera group (Amesiodendron, Paranephelium and Schleichera): type-B pollen and Cupanieae-type IV wood anatomy.

- Litchi group [Lepisantheae, Nephelieae (without Alectryon, Pappea, Podonephelium, Stadmania, Smelophyllum), Sapindeae (without Sapindus oligophyllus), Blighia, Eriocoelum, Haplocoelopsis, Laccodiscus, Lecaniodiscus, Lepidopetalum and Pseudima)]: to date, no morphological characters characterizing this group have been identified.

- Macphersonia group (Beguea, Conchopetalum, Haplocoelum perrieri, Macphersonia, Pappea, and Plagioscyphus): actinomorphic flowers and one ovule per locule (except two in Conchopetalum).
- Cupania group (Cupanieae [without Amesiodendron, Blighia, Blomia, Dictyoneura, Eriocoelum, Haplocoelopsis, Laccodiscus, Lepidopetalum, Pseudima], Alectryon, Podonephelium and Tinopsis): type-B pollen (except Alectryon and Podonephelium, which demonstrate type-A pollen).

- Tristiropsis group (Dictyoneura and Tristiropsis): to date, no morphological characters characterizing this group have been identified.

- Blomia group (Blomia and Haplocoelum foliosum): to date, no morphological characters characterizing this group have been identified.

- Melicoccus group (Talisia and Melicoccus): pollen type-A and Melicocceae wood anatomy.

- Paullinia group (Paullinieae, Thouinieae and Sapindus oligophyllus): imparipinnate leaves; zygomorphic flowers; petals with a prominent scale and a unilateral disk.

\subsection{Conclusions}

This study based on eight nuclear and plastid regions and $60.3 \%$ of the generic diversity of the Sapindaceae s.l. (152 samples and 139 species) (1) provides strong support for the monophyly of the family when Xanthoceras sorbifolia, Aceraceae and Hippocastanaceae are included (although relationships among subfamilies are still weakly supported), (2) highlights a high degree of paraphyly and polyphyly at subfamilial and tribal level, especially in Sapindaceae s.s. (subfamilies Dodonaeoideae and Sapindoideae) and (3) proposes a new informal classification for infrafamilial arrangements. Increased sampling, filled sequence gaps and the compilation of an extensive morphological matrix are now required to establish strong synapomorphies for each phylogenetic clade. A particular attention might be given to inflorescence types (and breeding systems) and floral morphology (e.g., shape and type of petal scale, type of disk, number of carpels, pubescence on the anthers, toxicity of the arillode). This might lead to a new formal infrafamilial classification for Sapindaceae s.l., based on the patterns highlighted in this study.

\section{Acknowledgments}

The first author would like to thank Professor Giorgina Bernasconi from the University of Neuchâtel (Switzerland) for help and financial support. We are grateful to the following people and institutions for the supply of plant material: the Conservatoire et Jardin botaniques de la ville de Genève (Switzerland); the Malagasy staff of the Missouri Botanical Garden in Antananarivo (Madagascar); Caroline Weckerle (University of Zürich, Switzerland); Laura Vary (University of California-Irvine; USA) and Jean-Noël Labat (Muséum d'Histoire Naturelle, Paris, France). The first author thank Yong-Ming Yuan (University of Neuchâtel, Switzerland) for providing laboratory support and plant material. We thank Nils Arrigo (University of Neuchâtel; Switzerland), Ken Wurdack (Smithsonian Institution, Washington, USA), Jérôme Munzinger (Laboratorie de Botanique, Centre IRD de Nouméa, Nouméa, New Caledonia), Peter Lowry II and Pete Phillipson (Missouri Botanical Garden, Saint-Louis; USA) for valuable comments on the manuscript and herbarium determinations. We thank the Associate Editor and two anonymous reviewers for numerous constructive comments that greatly improved the manuscript. 


\section{Appendix}

Voucher information and GenBank accession numbers for taxa used in the phylogenetic analysis of family Sapindaceae s.l. (including outgroups). Abbreviations: ANH, Andong

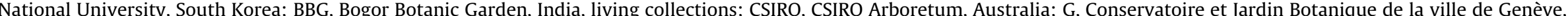

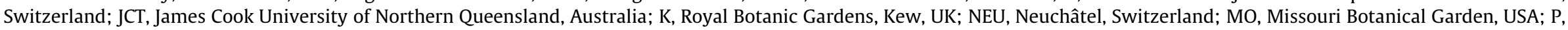
Muséum d'Histoire Naturelle, France; RBG, Royal Botanic Gardens, Kew, UK, living collections; US, Smithsonian Institution, USA; Z, University of Zürich, Switzerland.

\begin{tabular}{|c|c|c|c|c|c|c|c|c|c|c|c|c|c|}
\hline \multirow[t]{2}{*}{ Genera } & \multirow[t]{2}{*}{ Species } & \multirow[t]{2}{*}{ Author } & \multirow[t]{2}{*}{ Voucher } & \multirow[t]{2}{*}{ Herbarium } & \multirow[t]{2}{*}{ Country } & \multicolumn{8}{|c|}{ GenBank Accession Nos. } \\
\hline & & & & & & ITS & matK & гров & $\operatorname{trnD}-\operatorname{trnT}$ & trnK-matK & $\operatorname{trnL}$ & $\operatorname{trnL}-\mathrm{F}$ & $\operatorname{trnS}$-trnG \\
\hline \multicolumn{14}{|l|}{ Ingroup } \\
\hline Acer & erianthum & Schwer. & Chase 19983 & $\mathrm{~K}$ & China & EU720501 & - & EU720843 & EU720980 & - & EU721271 & EU721459 & - \\
\hline Acer & saccharum & Marshall & Chase 106 & K & $\begin{array}{l}\text { Cult. source, Orange } \\
\text { Co. }\end{array}$ & EU720502 & - & EU720844 & - & - & EU721272 & EU721460 & - \\
\hline Aesculus & indica & $\begin{array}{l}\text { (Wall. ex Cambess.) } \\
\text { Hook. }\end{array}$ & Chase 19987 & K & India & EU927392 & - & EU720845 & EU720981 & - & EU721273 & EU721461 & - \\
\hline Alectryon & connatus & Radlk. & Chase 2047 & $\mathrm{~K}$ & Australia & EU720415 & EU720577 & EU720732 & EU720928 & EU721025 & EU721169 & EU721357 & EU721534 \\
\hline Amesiodendron & chinensis & (Merr.) Hu & Yuan s.n. & NEU & China & EU720403 & - & EU720718 & EU720917 & - & EU721155 & EU721344 & EU721525 \\
\hline Arfeuillea & arborescens & Pierre & Chase 2122 & $\mathrm{~K}$ & Bogor, BG & EU720461 & EU720629 & EU720793 & EU720962 & EU721067 & EU721229 & EU721417 & - \\
\hline Arytera & littoralis & Blume & Yuan s.n. & NEU & China & EU720405 & EU720566 & EU720720 & EU720919 & EU721018 & EU721157 & EU721346 & EU721527 \\
\hline Arytera & littoralis & Blume & Chase 2123 & $\mathrm{~K}$ & Bogor, BG & EU720462 & EU720630 & EU720794 & EU720963 & EU721068 & EU721230 & EU721418 & - \\
\hline Atalaya & alata & (Sim) H. Forbes & Edwards KE228 & JCT & South Africa & EU720425 & EU720593 & EU720748 & EU720939 & EU721036 & EU721184 & EU721372 & EU721543 \\
\hline Atalaya & capense & R.A. Dyer & Edwards KE 509 & JCT & South Africa & EU720429 & - & EU720752 & - & - & EU721188 & EU721376 & - \\
\hline Athyana & weinmannifolia & (Griseb.) Radlk. & Pennington 17581 & MO & Peru & EU720487 & EU720649 & EU720824 & EU720975 & EU721086 & EU721257 & EU721445 & EU721576 \\
\hline Averrhoidium & dalyi & Acev.-Rodr. \& Ferrucci & $\begin{array}{l}\text { Weckerle 00/03/ } \\
18-1 / 1\end{array}$ & $\mathrm{Z}$ & Peru & EU720495 & - & EU720836 & - & - & EU721268 & EU721456 & - \\
\hline Веguea & apetala & Capuron & Buerki 149 & NEU & Madagascar & EU720491 & EU720652 & EU720828 & EU720978 & EU721089 & EU721261 & EU721449 & - \\
\hline Beguea & apetala & Capuron & Vary 40 & MO & Madagascar & EU720512 & EU720663 & EU720856 & - & EU721100 & EU721281 & EU721469 & - \\
\hline Blighia & sapida & K.D. Koenig & Edwards KE86 & JCT & West Africa & EU720416 & EU720578 & EU720733 & EU720929 & EU721026 & EU721170 & EU721358 & EU721535 \\
\hline Blomia & prisca & (Standl.) Lundell & Acevedo 12242 & US & Mexico, Yucatan & EU720444 & EU720611 & EU720772 & - & EU721050 & EU721208 & EU721396 & - \\
\hline Bridgesia & incisifolia & Bertero ex Cambess. & $\begin{array}{l}\text { Killip E Pisano } \\
39778\end{array}$ & $\mathrm{~K}$ & Chile & EU720476 & EU720645 & EU720811 & EU720973 & EU721082 & EU721247 & EU721435 & - \\
\hline Cardiospermum & sp. & & Yuan s.n. & NEU & China & EU720399 & - & EU720713 & EU720912 & - & EU721150 & EU721339 & - \\
\hline Chytranthus & carneus & Radlk. & Chase 2868 & RBG & - & EU720477 & EU720646 & EU720812 & EU720974 & EU721083 & EU721248 & EU721436 & EU721575 \\
\hline Conchopetalum & brachysepalum & Capuron & Rabarimanarivo 8 & MO & Madagascar & EU720530 & EU720680 & EU720877 & - & EU721117 & EU721299 & EU721487 & EU721586 \\
\hline Cubilia & cubili & (Blanco) Adelb. & Chase 2125 & $\mathrm{~K}$ & Bogor, BG & EU720463 & EU720631 & EU720795 & EU720964 & EU721069 & EU721231 & EU721419 & EU721567 \\
\hline Cupania & dentata & DC. & Acevedo 12241 & US & Mexico, Yucatan & EU720523 & EU720670 & EU720867 & EU720988 & EU721107 & EU721289 & EU721477 & EU721581 \\
\hline Cupania & hirsuta & Radlk. & Acevedo 1101 & US & French Guiana & EU720521 & EU720668 & EU720865 & - & EU721105 & EU721287 & EU721475 & - \\
\hline Cupania & rubiginosa & (Poir.) Radlk. & Mori 8868 & MO & French Guiana & EU720481 & - & EU720817 & - & - & EU721251 & EU721439 & - \\
\hline Cupania & scrobiculata & Rich. & Acevedo 11100 & US & French Guiana & EU720524 & EU720671 & EU720868 & EU720989 & EU721108 & EU721290 & EU721478 & - \\
\hline Cupaniopsis & anacardioides & Radlk. & Chase 217 & $\mathrm{~K}$ & Australia & EU720438 & EU720605 & EU720763 & EU720946 & EU721045 & EU721199 & EU721387 & EU721552 \\
\hline Cupaniopsis & flagelliformis & (Bailey) Radlk. & Edwards KE42 & JCT & Australia & EU720432 & EU720598 & EU720755 & EU720942 & - & EU721191 & EU721379 & EU721547 \\
\hline Cupaniopsis & fruticosa & Radlk. & Munzinger 564 & MO & New Caledonia & EU720533 & - & EU720881 & - & EU721119 & EU721302 & EU721490 & - \\
\hline Cupaniopsis & sp. & & Munzinger 710 & MO & New Caledonia & EU720532 & - & EU720880 & EU720996 & - & EU721301 & EU721489 & EU721587 \\
\hline Cupaniopsis & sp. & & Munzinger 1103 & MO & New Caledonia & EU720507 & EU720660 & EU720851 & - & EU721097 & EU721278 & EU721466 & - \\
\hline Deinbollia & borbonica & Scheff. & Edwards KE197 & JCT & Tanzania & EU720412 & EU720574 & EU720729 & - & - & EU721166 & EU721354 & EU721532 \\
\hline Deinbollia & macrocarpa & Capuron & $\begin{array}{l}\text { H. Razafindraibe } \\
118\end{array}$ & MO & Madagascar & EU720535 & EU720683 & EU720883 & - & EU721121 & EU721304 & EU721492 & EU721589 \\
\hline Deinbollia & macrocarpa & Capuron & Buerki 144 & NEU & Madagascar & EU720503 & EU720656 & EU720847 & - & EU721093 & EU721275 & EU721463 & - \\
\hline Deinbollia & oblongifolia & $\begin{array}{l}\text { (E. Mey. ex Arn.) } \\
\text { Radlk. }\end{array}$ & Edwards KE233 & JCT & South Africa & EU720427 & EU720595 & EU720750 & - & - & EU721186 & EU721374 & EU721545 \\
\hline Deinbollia & pervillei & (Blume) Radlk. & Phillipson 5919 & MO & Madagascar & EU720395 & EU720560 & EU720708 & - & EU721012 & EU721145 & EU721334 & - \\
\hline Deinbollia & pervillei & (Blume) Radlk. & Callmander 688 & MO & Madagascar & EU720514 & - & EU720858 & - & - & EU721283 & $\begin{array}{l}\text { EU721471 } \\
\text { (continued o }\end{array}$ & $\begin{array}{l}- \\
\text { on next page) }\end{array}$ \\
\hline
\end{tabular}




\begin{tabular}{|c|c|c|c|c|c|c|c|c|c|c|c|c|c|}
\hline \multirow[t]{2}{*}{ Genera } & \multirow[t]{2}{*}{ Species } & \multirow[t]{2}{*}{ Author } & \multirow[t]{2}{*}{ Voucher } & \multirow[t]{2}{*}{ Herbarium } & \multirow[t]{2}{*}{ Country } & \multicolumn{8}{|c|}{ GenBank Accession Nos. } \\
\hline & & & & & & ITS & matK & гров & $\operatorname{trnD}-\operatorname{trnT}$ & trnK-matK & $\operatorname{trnL}$ & trnL-F & trnS-trnG \\
\hline Delavaya & yunnanensis & Franch. & Forrest 20682 & MO & $\begin{array}{l}\text { China, } \\
\text { Yunnan }\end{array}$ & EU720484 & - & EU720821 & - & - & EU721254 & EU721442 & - \\
\hline Diatenopteryx & sorbifolia & Radlk. & Zardini 43371 & MO & Paraguay & EU720534 & EU720682 & EU720882 & - & EU721120 & EU721303 & EU721491 & EU721588 \\
\hline Dictyoneura & obtusa & Blume & Edwards KE142 & JCT & Australia & EU720428 & - & EU720751 & - & - & EU721187 & EU721375 & - \\
\hline Dimocarpus & australianus & Leenh. & Edwards KE34 & JCT & Australia & EU720433 & - & EU720757 & - & - & EU721193 & EU721381 & - \\
\hline Diploglottis & campbelli & Cheel & Chase 2048 & $\mathrm{~K}$ & $\begin{array}{l}\text { Australian, } \\
\text { BG }\end{array}$ & EU720457 & EU720624 & EU720788 & EU720960 & EU721062 & EU721224 & EU721412 & - \\
\hline Diplopeltis & huegelii & Endl. & Chase 2192 & $\mathrm{~K}$ & Australia & EU720473 & EU720642 & EU720807 & EU720971 & EU721079 & EU721243 & EU721431 & - \\
\hline Dipteronia & sinensis & Oliv. & Chase 502 & RBG & - & EU720445 & EU720612 & EU720774 & - & - & EU721210 & EU721398 & - \\
\hline Dodonaea & madagascariensis & Radlk. & Bocksberger GB028 & NEU & Madagascar & EU720518 & & EU720862 & EU720984 & - & EU721284 & EU721472 & - \\
\hline Dodonaea & viscosa & Jacq. & Razafitsalama 956 & MO & Madagascar & EU720519 & EU720666 & EU720863 & EU720985 & EU721103 & EU721285 & EU721473 & - \\
\hline Dodonaea & viscosa & Jacq. & Merello 1077 & MO & Peru & EU720536 & EU720684 & EU720884 & EU720997 & EU721122 & EU721305 & EU721493 & - \\
\hline Dodonaea & viscosa & Jacq. & Yuan s.n. & NEU & China & EU720406 & EU720567 & EU720721 & EU720920 & EU721019 & EU721158 & EU721347 & - \\
\hline Doratoxylon & chouxii & Capuron & Labat JNL3543 & $\mathrm{P}$ & Madagascar & EU720394 & EU720559 & EU720707 & EU720908 & EU721011 & EU721144 & EU721333 & - \\
\hline Doratoxylon & chouxii & Capuron & Callmander 679 & MO & Madagascar & EU720513 & EU720664 & EU720857 & - & EU721101 & EU721282 & EU721470 & - \\
\hline Elattostachys & apetala & Radlk. & Munzinger 692 & MO & $\begin{array}{l}\text { New } \\
\text { Caledonia }\end{array}$ & EU720537 & EU720685 & EU720885 & EU720998 & EU721123 & EU721306 & EU721494 & EU721590 \\
\hline Elattostachys & apetala & Radlk. & McPherson 18184 & MO & $\begin{array}{l}\text { New } \\
\text { Caledonia }\end{array}$ & EU720538 & EU720686 & EU720886 & EU720999 & EU721124 & EU721307 & EU721495 & EU721591 \\
\hline Elattostachys & microcarpa & S.T. Reynolds & Edwards KE98 & JCT & Australia & EU720409 & EU720571 & EU720726 & - & - & EU721163 & EU721351 & - \\
\hline Elattostachys & nervosa & (F. Muell.) Radlk. & Chase 2022 & $\mathrm{~K}$ & $\begin{array}{l}\text { Australian, } \\
\text { BG }\end{array}$ & EU720455 & EU720622 & EU720786 & EU720959 & EU721060 & EU721222 & EU721410 & EU721563 \\
\hline Elattostachys & sp. & & Lowry $5650 A$ & MO & $\begin{array}{l}\text { New } \\
\text { Caledonia }\end{array}$ & EU720529 & EU720679 & EU720876 & EU720994 & EU721116 & EU721298 & EU721486 & EU721585 \\
\hline Eriocoelum & kerstingii & Gilg ex Engl. & Merello 1586 & MO & Ghana & EU720539 & EU720687 & EU720887 & EU721000 & EU721125 & EU721308 & EU721496 & EU721592 \\
\hline Eriocoelum & microspermum & Radlk. & Bradley 1025 & MO & Gabon & EU720540 & EU720688 & EU720888 & EU721001 & EU721126 & EU721309 & EU721497 & EU721593 \\
\hline Euphorianthus & longifolius & Radlk. & Chase 2126 & $\mathrm{~K}$ & Bogor, BG & EU720464 & - & EU720796 & - & - & EU721232 & EU721420 & - \\
\hline Eurycorymbus & cavalerieri & $\begin{array}{l}\text { (H. Lév.) Rehder \& Hand.- } \\
\text { Mazz. }\end{array}$ & Yuan s.n. & NEU & China & EU720404 & EU720565 & EU720719 & EU720918 & EU721017 & EU721156 & EU721345 & EU721526 \\
\hline Filicium & decipiens & (Wight \& Arn.) Thwaites & Chase 2128 & $\mathrm{~K}$ & Bogor, BG & EU720466 & EU720633 & EU720798 & - & - & EU721234 & EU721422 & - \\
\hline Filicium & longifolium & (H. Perrier) Capuron & $\begin{array}{l}\text { Rabenantonadro } \\
1113\end{array}$ & MO & Madagascar & EU720541 & - & EU720889 & - & - & EU721310 & EU721498 & - \\
\hline Filicium & thouarsianum & (A. DC.) Capuron & Antilahimena 5021 & MO & Madagascar & EU720493 & - & EU720832 & - & - & EU721265 & EU721453 & - \\
\hline Ganophyllum & falcatum & Blume & Chase 2129 & $\mathrm{~K}$ & Bogor, BG & EU720467 & EU720634 & EU720799 & - & EU721071 & EU721235 & EU721423 & - \\
\hline Glenniea & pervillei & (Baill.) Leenh. & $\begin{array}{l}\text { Andriamihajarivo } \\
1053\end{array}$ & MO & Madagascar & EU720490 & EU720651 & EU720827 & EU720977 & EU721088 & EU721260 & EU721448 & - \\
\hline Gongrodiscus & bilocularis & H.Turner & Munzinger 749 & MO & $\begin{array}{l}\text { New } \\
\text { Caledonia }\end{array}$ & EU720542 & EU720689 & EU720890 & - & EU721127 & EU721311 & EU721499 & - \\
\hline Guioa & glauca & Radlk. & McPherson 18230 & MO & $\begin{array}{l}\text { New } \\
\text { Caledonia }\end{array}$ & EU720545 & EU720692 & EU720893 & - & EU721130 & EU721315 & EU721503 & - \\
\hline Guioa & microsepala & Radlk. & Munzinger 744 & MO & $\begin{array}{l}\text { New } \\
\text { Caledonia }\end{array}$ & EU720546 & EU720693 & EU720894 & - & EU721131 & EU721316 & EU721504 & EU721596 \\
\hline Guioa & semiglauca & (F. Muell.) Radlk. & Chase 2058 & K & $\begin{array}{l}\text { Australian, } \\
\text { BG }\end{array}$ & EU720458 & EU720625 & EU720789 & - & EU721063 & EU721225 & EU721413 & - \\
\hline Guioa & villosa & Radlk. & McPherson 18040 & MO & $\begin{array}{l}\text { New } \\
\text { Caledonia }\end{array}$ & EU720544 & EU720691 & EU720892 & EU721003 & EU721129 & EU721314 & EU721502 & EU721595 \\
\hline Guioa & sp. & & Munzinger 945 & MO & $\begin{array}{l}\text { New } \\
\text { Caledonia }\end{array}$ & EU720505 & EU720658 & EU720849 & - & EU721095 & EU721277 & EU721465 & - \\
\hline Haplocoelopsis & africana & F.G. Davies & Edwards KE276 & JCT & Tanzania & EU720441 & EU720608 & EU720767 & EU720949 & - & EU721203 & EU721391 & EU721555 \\
\hline Haplocoelum & foliosum & (Hiern) Bullock & Friis 1894 & MO & Ethiopia & EU720479 & - & EU720815 & - & - & EU721250 & EU721438 & - \\
\hline Haplocoelum & foliosum subsp. foliosum & (Hiern) Bullock & Edwards KE195 & JCT & Tanzania & EU720410 & EU720572 & EU720727 & EU720924 & - & EU721164 & EU721352 & EU721530 \\
\hline Haplocoelum & perrieri & Capuron & Rakotomalaza 1165 & MO & Madagascar & EU720396 & - & EU720709 & EU720909 & - & EU721146 & EU721335 & EU721519 \\
\hline Harpullia & arborea & (Blanco) Radlk. & Chase 1353 & $\mathrm{~K}$ & Bogor, BG & EU720448 & - & EU720779 & - & - & EU721215 & EU721403 & - \\
\hline Jagera & javanica & (Blume) Blume ex Kalkman & Chase 2130 & $\mathrm{~K}$ & Bogor, BG & EU720468 & EU720635 & EU720800 & - & EU721072 & EU721236 & EU721424 & EU721569 \\
\hline Jagera & javanica subsp. australiana & Leenh. & Edwards KE178 & JCT & Australia & EU720442 & - & EU720769 & - & - & EU721205 & EU721393 & EU721556 \\
\hline Koelreuteria & paniculata & Laxm. & Harder 5668 & MO & Vietnam & EU720548 & EU720695 & EU720896 & - & EU721133 & EU721318 & EU721506 & - \\
\hline Koelreuteria & paniculata & Laxm. & Yuan CN2006-3 & NEU & China & EU720397 & EU720561 & EU720710 & - & EU721013 & EU721147 & EU721336 & EU721520 \\
\hline
\end{tabular}




\begin{tabular}{|c|c|c|c|c|c|c|c|c|c|c|c|c|c|}
\hline Koelreuteria & sp. & & Harder 5724 & MO & Vietnam & EU720547 & EU720694 & EU720895 & EU721004 & EU721132 & EU721317 & EU721505 & - \\
\hline Laccodiscus & klaineanus & Pierre ex Engl. & Walters 1269 & MO & Gabon & EU720549 & EU720696 & EU720897 & - & EU721134 & EU721319 & EU721507 & - \\
\hline Lecaniodiscus & fraxinifolius & Baker & Edwards KE194 & JCT & Tanzania & EU720418 & EU720580 & EU720735 & EU720931 & EU721028 & EU721172 & EU721360 & EU721536 \\
\hline Lepiderema & hirsuta & S.T. Reynolds & Edwards KE36 & JCT & Australia & EU720435 & EU720601 & EU720759 & - & EU721041 & EU721195 & EU721383 & EU721549 \\
\hline Lepiderema & pulchella & Radlk. & Chase 2020 & $\mathrm{~K}$ & $\begin{array}{l}\text { Australian, } \\
\text { BG }\end{array}$ & EU720454 & - & EU720785 & EU720958 & - & EU721221 & EU721409 & - \\
\hline Lepidopetalum & fructoglabrum & Welzen & Edwards KE139 & JCT & Australia & EU720408 & - & EU720724 & EU720922 & - & EU721161 & EU721349 & EU721528 \\
\hline Lepisanthes & alata & (Blume) Leenh. & Chase 1355 & $\mathrm{~K}$ & Bogor, BG & EU720450 & EU720618 & EU720781 & - & EU721056 & EU721217 & EU721405 & - \\
\hline Lepisanthes & feruginea & (Radlk.) Leenh. & Chase 1354 & K & Bogor, BG & EU720449 & EU720617 & EU720780 & - & EU721055 & EU721216 & EU721404 & - \\
\hline Lepisanthes & rubiginosa & (Roxb.) Leenh. & Chase 1350 & $\mathrm{~K}$ & Bogor, BG & EU720446 & EU720614 & EU720776 & EU720952 & EU721052 & EU721212 & EU721400 & EU721558 \\
\hline Lepisanthes & senegalensis & (Poir.) Leenh. & Callmander 627 & MO & Madagascar & EU720492 & EU720654 & EU720830 & EU720979 & EU721091 & EU721263 & EU721451 & EU721577 \\
\hline Litchi & chinensis & Sonn. & Yuan s.n. & NEU & China & EU720400 & EU720564 & EU720715 & EU720914 & EU721016 & EU721152 & EU721341 & EU721522 \\
\hline Llagunoa & mollis & Kunth & Jaramillollejia 3199 & MO & Colombia & EU720482 & - & EU720818 & - & - & EU721252 & EU721440 & - \\
\hline Llagunoa & nitida & Ruiz \& Pav. & Pennington 17552 & MO & Peru & EU720486 & - & EU720823 & - & - & EU721256 & EU721444 & - \\
\hline Loxodiscus & coriaceus & Hook. f. & Bradford 1136 & MO & $\begin{array}{l}\text { New } \\
\text { Caledonia }\end{array}$ & EU720488 & - & EU720825 & - & - & EU721258 & EU721446 & - \\
\hline Macphersonia & chapelieri & (Baill.) Capuron & Buerki 138 & NEU & Madagascar & EU720459 & EU720627 & EU720791 & EU720961 & EU721065 & EU721227 & EU721415 & EU721566 \\
\hline Macphersonia & gracilis & O. Hoffm. & $\begin{array}{l}\text { Rabenantoandro } \\
1081\end{array}$ & MO & Madagascar & EU720550 & EU720697 & EU720898 & EU721005 & EU721135 & EU721320 & EU721508 & EU721597 \\
\hline Majidea & zanguebarika & Kirk ex Oliv. & TH275 & MO & Madagascar & EU720552 & - & EU720900 & EU721006 & - & EU721322 & EU721510 & - \\
\hline Matayba & apetala & Radlk. & Acevedo 11929 & US & Jamaica & EU720526 & EU720674 & EU720871 & - & EU721111 & EU721293 & EU721481 & EU721583 \\
\hline Matayba & cf. opaca & Radlk. & Acevedo 11118 & US & $\begin{array}{l}\text { French } \\
\text { Guiana }\end{array}$ & EU720522 & EU720669 & EU720866 & EU720987 & EU721106 & EU721288 & EU721476 & EU721580 \\
\hline Matayba & domingensis & (DC.) Radlk. & Taylor 11819 & MO & Caribbean & EU720551 & EU720698 & EU720899 & - & EU721136 & EU721321 & EU721509 & EU721598 \\
\hline Matayba & elaeagnoides & Radlk. & Zardini 43278 & MO & Paraguay & EU720553 & EU720699 & EU720901 & - & EU721137 & EU721323 & EU721511 & - \\
\hline Matayba & guianensis & Aubl. & Acevedo 12342 & US & $\begin{array}{l}\text { French } \\
\text { Guiana }\end{array}$ & EU720527 & EU720675 & EU720872 & - & EU721112 & EU721294 & EU721482 & - \\
\hline Matayba & laevigata & Radlk. & Acevedo 12357 & US & $\begin{array}{l}\text { French } \\
\text { Guiana }\end{array}$ & EU720528 & EU720676 & EU720873 & EU720992 & EU721113 & EU721295 & EU721483 & - \\
\hline Melicoccus & bijugatus & Jacq. & Acevedo s.n. & US & Puerto Rico & EU927391 & EU720610 & EU720771 & - & EU721049 & EU721207 & EU721395 & - \\
\hline Melicoccus & lepidopetalus & Radlk. & Acevedo 11128 & US & Bolivia & EU720443 & - & EU720770 & - & - & EU721206 & EU721394 & - \\
\hline Mischarytera & sp. & - & Edwards KE159 & JCT & Australia & EU720417 & EU720579 & EU720734 & EU720930 & EU721027 & EU721171 & EU721359 & - \\
\hline Mischocarpus & exangulatus & (F. Muell.) Radlk. & Edwards KE30 & JCT & Australia & EU720434 & EU720600 & EU720758 & EU720943 & EU721040 & EU721194 & EU721382 & - \\
\hline Mischocarpus & grandissumus & Radlk. & Edwards KE37 & JCT & Australia & EU720437 & EU720604 & EU720762 & EU720945 & EU721044 & EU721198 & EU721386 & EU721551 \\
\hline Mischocarpus & pentapetalus & (Rox.) Radlk. & Chase 2133 & $\mathrm{~K}$ & Bogor, BG & EU720470 & EU720637 & EU720802 & EU720966 & EU721074 & EU721238 & EU721426 & EU721571 \\
\hline Mischocarpus & pyriformis & (F. Muell.) Radlk. & Chase 2059 & K & $\begin{array}{l}\text { Australian, } \\
\text { BG }\end{array}$ & EU720460 & EU720628 & EU720792 & - & EU721066 & EU721228 & EU721416 & - \\
\hline Molinaea & petiolaris & Radlk. & $\begin{array}{l}\text { Rabenantoandro } \\
1448\end{array}$ & MO & Madagascar & EU720554 & EU720700 & EU720902 & EU721007 & EU721138 & EU721324 & EU721512 & - \\
\hline Molinaea & sp. nov. & & Antilahimena 4301 & MO & Madagascar & EU720510 & EU720662 & EU720854 & EU720983 & EU721099 & EU721280 & EU721468 & EU721578 \\
\hline Neotina & coursii & Capuron & H. Razafindraibe 119 & MO & Madagascar & EU720543 & EU720690 & EU720891 & EU721002 & EU721128 & EU721313 & EU721501 & EU721594 \\
\hline Nephelium & lappaceum (=N. chryseum) & L. & Yuan s.n. & NEU & China & EU720401 & - & EU720716 & EU720915 & - & EU721153 & EU721342 & EU721523 \\
\hline Pancovia & golungensis & (Hiern) Exell \& Mendonça & Edwards KE231 & JCT & Tanzania & EU720411 & EU720573 & EU720728 & EU720925 & EU721022 & EU721165 & EU721353 & EU721531 \\
\hline Pappea & capensis & Eckl. \& Zeyh. & Edwards KE232 & JCT & South Africa & EU720424 & EU720592 & EU720747 & EU720938 & EU721035 & EU721183 & EU721371 & EU721542 \\
\hline Paranephelium & macrophyllum & King & Chase 1356 & $\mathrm{~K}$ & Bogor, BG & EU720451 & EU720619 & EU720782 & EU720955 & EU721057 & EU721218 & EU721406 & - \\
\hline Paranephelium & xestophyllum & Miq. & Edrwards KE503 & JCT & Asia & EU720420 & EU720582 & EU720737 & - & EU721029 & EU721174 & EU721362 & - \\
\hline Paullinia & pinnata & L. & Edwards KE199 & JCT & Tanzania & EU720413 & EU720575 & EU720730 & EU720926 & EU721023 & EU721167 & EU721355 & - \\
\hline Paullinia & subauriculata & Radlk. & $\begin{array}{l}\text { Weckerle 00/03/19- } \\
1 / 1\end{array}$ & $\mathrm{Z}$ & Peru & EU720494 & - & EU720833 & - & - & EU721266 & EU721454 & - \\
\hline Plagioscyphus & aff. louvelii & Danguy \& Choux & Lowry 6034 & MO & Madagascar & EU720555 & EU720701 & EU720903 & EU721008 & EU721139 & EU721325 & EU721513 & EU721599 \\
\hline Plagioscyphus & unijugatus & Capuron & Buerki 145 & NEU & Madagascar & EU720475 & EU720644 & EU720809 & EU720972 & EU721081 & EU721245 & EU721433 & EU721574 \\
\hline Podonephelium & homei & Radlk. & Pillon 156 & MO & $\begin{array}{l}\text { New } \\
\text { Caledonia }\end{array}$ & EU720489 & EU720650 & EU720826 & EU720976 & EU721087 & EU721259 & EU721447 & - \\
\hline Pometia & pinnata & J.R. Forst. \& G. Forst. & Chase 2135 & $\mathrm{~K}$ & Bogor, BG & EU720471 & EU720638 & EU720803 & EU720967 & EU721075 & EU721239 & EU721427 & EU721572 \\
\hline Pometia & pinnata & J.R. Forst. \& G. Forst. & Yuan s.n. & NEU & China & EU720402 & - & EU720717 & EU720916 & - & EU721154 & EU721343 & EU721524 \\
\hline Pseudima & sp. & & McPherson 15867 & MO & Panama & EU720556 & EU720702 & EU720904 & EU721009 & EU721140 & EU721326 & EU721514 & EU721600 \\
\hline Rhysotoechia & mortoniana & (F. Muell.) Radlk. & Edwards KE117 & JCT & Australia & EU720414 & EU720576 & EU720731 & EU720927 & EU721024 & EU721168 & EU721356 & EU721533 \\
\hline Sapindus & $\begin{array}{l}\text { oligophyllus (=Aphania } \\
\text { oligophylla) }\end{array}$ & Merr. \& Chun & Yuan s.n. & NEU & China & EU720407 & EU720568 & EU720722 & EU720921 & EU721020 & EU721159 & EU721159 & - \\
\hline Sarcopteryx & martyana & (F. Muell.) Radlk. & Irvine IRV1810 & CSIRO & Australia & EU720426 & EU720594 & EU720749 & EU720940 & EU721037 & EU721185 & EU721373 & EU721544 \\
\hline Sarcopteryx & reticulata & S.T. Reynolds & Gray BG1137 & CSIRO & Australia & EU720421 & EU720587 & EU720741 & - & EU721033 & EU721178 & $\begin{array}{l}\text { EU721366 } \\
\text { (continued on }\end{array}$ & $\begin{array}{r}\text { EU721539 } \\
\text { n next page) }\end{array}$ \\
\hline
\end{tabular}




\begin{tabular}{|c|c|c|c|c|c|c|c|c|c|c|c|c|c|}
\hline \multirow[t]{2}{*}{ Genera } & \multirow[t]{2}{*}{ Species } & \multirow[t]{2}{*}{ Author } & \multirow[t]{2}{*}{ Voucher } & \multirow[t]{2}{*}{ Herbarium } & \multirow[t]{2}{*}{ Country } & \multicolumn{8}{|c|}{ GenBank Accession Nos. } \\
\hline & & & & & & ITS & matK & гров & $\operatorname{trnD}-\operatorname{trn} T$ & trnK-matK & $\operatorname{trnL}$ & trnL-F & trnS-trnG \\
\hline Sarcopteryx & sp. & - & Edwards KE49 & JCT & Australia & EU720439 & EU720607 & EU720765 & EU720948 & EU721047 & EU721201 & EU721389 & EU721554 \\
\hline Sarcotoechia & serrata & S.T. Reynolds & Edwards KE31 & JCT & Australia & EU720436 & EU720603 & EU720761 & EU720944 & EU721043 & EU721197 & EU721385 & EU721550 \\
\hline Sarcotoechia & villosa & S.T. Reynolds & Edwards KE102 & JCT & Australia & EU720419 & EU720581 & EU720736 & - & - & EU721173 & EU721361 & - \\
\hline Schleichera & oleosa & (Lour.) Oken & Chase 2137 & $\mathrm{~K}$ & Bogor, BG & EU720423 & EU720591 & EU720746 & EU720937 & - & EU721182 & EU721370 & EU721541 \\
\hline Serjania & altissima & (Poepp.) Radlk. & Weckerle 00/07/02-1/4 & Z & Peru & EU720498 & - & EU720840 & - & - & EU721269 & EU721457 & - \\
\hline Serjania & communis & Cambess. & Chase 2138 & $\mathrm{~K}$ & Bogor, BG & EU720472 & EU720640 & EU720805 & EU720969 & EU721077 & EU721241 & EU721429 & - \\
\hline Serjania & glabrata & Kunth & Merello 1058 & MO & Peru & EU720557 & EU720703 & EU720905 & EU721010 & EU721141 & EU721327 & EU721515 & - \\
\hline Storthocalyx & sp. & & Munzinger 960 & MO & New Caledonia & EU720504 & EU720657 & EU720848 & - & EU721094 & EU721276 & EU721464 & - \\
\hline Synima & macrophylla & S.T. Reynolds & Edwards KE19 & JCT & Australia & EU720430 & EU720596 & EU720753 & EU720941 & - & EU721189 & EU721377 & EU721546 \\
\hline Talisia & angustifolia & Radlk. & Zardini 43668 & MO & Paraguay & EU720558 & EU720705 & EU720907 & - & EU721143 & EU721328 & EU721516 & - \\
\hline Talisia & nervosa & Radlk. & Pennington 628 & MO & - & EU720474 & EU720643 & EU720808 & - & EU721080 & EU721244 & EU721432 & - \\
\hline Talisia & obovata & A.C. Sm. & R.Lombello 13 & MO & Brazil & EU720485 & EU720648 & EU720822 & - & EU721085 & EU721255 & EU721443 & - \\
\hline Thouinia & acuminata & S. Watson & Liston 633-2 & MO & Mexico, Jalisco & EU720478 & EU720647 & EU720814 & - & EU721084 & EU721249 & EU721437 & - \\
\hline Tina & isaloensis & Drake & Ranirison PR827 & G & Madagascar & EU720520 & EU720667 & EU720864 & EU720986 & EU721104 & EU721286 & EU721474 & EU721579 \\
\hline Tina & striata & Radlk. & Vary 45 & MO & Madagascar & EU720509 & EU720661 & EU720853 & - & EU721098 & EU721279 & EU721467 & - \\
\hline Tinopsis & apiculata & Radlk. & Buerki 131 & NEU & Madagascar & EU720422 & EU720589 & EU720744 & EU720936 & EU721034 & EU721180 & EU721368 & EU721540 \\
\hline Toechima & erythrocarpum & (F. Muell.) Radlk. & Edwards KE20 & JCT & Australia & EU720431 & EU720597 & EU720754 & - & EU721038 & EU721190 & EU721378 & - \\
\hline Toechima & plurinerve & Radlk. & Chase 1357 & $\mathrm{~K}$ & Bogor, BG & EU720452 & EU720620 & EU720783 & EU720956 & EU721058 & EU721219 & EU721407 & EU721561 \\
\hline Toechima & tenax & (Cunn. ex Benth.) Radlk. & Chase 2046 & $\mathrm{~K}$ & Australian, BG & EU720456 & EU720623 & EU720787 & - & EU721061 & EU721223 & EU721411 & EU721564 \\
\hline Toechima & tenax & (Cunn. ex Benth.) Radlk. & Chase 2132 & $\mathrm{~K}$ & Bogor, BG & EU720469 & EU720636 & EU720801 & EU720965 & EU721073 & EU721237 & EU721425 & EU721570 \\
\hline Tristiropsis & acutangula & Radlk. & Chase 1358 & $\mathrm{~K}$ & Bogor, BG & EU720453 & EU720621 & EU720784 & EU720957 & EU721059 & EU721220 & EU721408 & EU721562 \\
\hline Urvillea & ulmaceae & Kunth & Weckerle 00/07/05-1/1 & $\mathrm{Z}$ & Peru & EU720499 & EU720655 & EU720841 & - & EU721092 & EU721270 & EU721458 & - \\
\hline Vouarana & guianensis & Aubl. & Lucas 109 & MO & French Guiana & EU720525 & EU720673 & EU720870 & EU720991 & EU721110 & EU721292 & EU721480 & EU721582 \\
\hline $\begin{array}{l}\text { Xanthoceras } \\
\text { Outroup }\end{array}$ & sorbifolium & Bunge & Yuan CN2006 & NEU & China & EU720398 & EU720562 & EU720711 & EU720910 & EU721014 & EU721148 & EU721337 & - \\
\hline Sorindeia & & & Buerki 137 & NEU & Madagascar & - & - & EU720831 & - & - & EU721264 & EU721452 & - \\
\hline Harrisonia & abyssinica & Oliv. & Edwards KE510 & JCT & Tanzania & EU720440 & - & EU720766 & - & - & EU721202 & EU721390 & - \\
\hline
\end{tabular}




\section{References}

Acevedo-Rodríguez, P., 1993a. A revision of Lophostigma (Sapindaceae). Syst. Bot. $18,379-388$

Acevedo-Rodríguez, P., 1993b. Systematics of Serjania (Sapindaceae). I. A Revision of Serjania Sect. Platycoccus. New York Botanical Garden, New York.

Acevedo-Rodríguez, P., 2003. Melicocceae (Sapindaceae): Melicoccus and Talisia. Flora Neotropica Monogr. 87, 1-179.

Adema, F., 1991. Cupaniopsis Radlk. (Sapindaceae): a monograph. Leiden Botanical Series 15, 1-190.

Adema, F., Leenhouts, P.W., van Welzen, P.C., 1994. Sapindaceae. Flora Malesiana Ser. I 11, 419-768.

Akaike, H., 1973. Information theory and an extension of the maximum likelihood principle. In: Akademiai Kiado (Ed.), Second International Symposium on Information Theory, Budapest, pp. 267-281.

Angiosperm Phylogeny Group (APGII), 2003. An update of the Angiosperm Phylogeny Group classification for the orders and families of flowering plants: APGII. Bot. J. Linn. Soc. 141, 399-436.

Baldwin, B.G., 1992. Phylogenetic utility of the internal transcribed spacers of nuclear ribosomal DNA in plants: an example from the Compositae. Mol. Phylogenet. Evol. 1, 3-16.

Bapteste, E., Brinkmann, H., Lee, J.A., Moore, D.V., Sensen, C.W., Gordon, P., Durufle, L., Gaasterland, T., Lopez, P., Müller, M., Philippe, H., 2002. The analysis of 100 genes supports the grouping of three highly divergent amoebae: Dictyostelium Entamoeba, and Mastigamoeba. Proc. Natl. Acad. Sci. USA 99, 1414-1419.

Biesboer, D.D., 1975. Pollen morphology of the Aceraceae. Grana 15, 19-27.

Capuron, R., 1969. Révision des Sapindacées de Madagascar et des Comores. Mém. Mus. Natl. Hist. Nat. B Bot. 19, 1-189.

Chase, M.W., Hills, H.H., 1991. Silica-gel - an ideal material for field preservation of leaf samples for DNA studies. Taxon 40, 215-220.

Clayton, J.W., Fernando, E.S., Soltis, P.S., Soltis, D.E., 2007. Molecular phylogeny of the tree-of-heaven family (Simaroubaceae) based on chlorplast and nuclear markers. Int. J. Plant Sci. 168, 1325-1339.

Cronquist, A., 1988. The Evolution and Classification of Flowering Plants, second ed. New York Botanic Gardens, New York.

Dahlgren, G., 1989. An updated system of classification. Bot. J. Linn. Soc. 100, 197203.

Davies, F.G., 1997. A new genus Haplocoelopsis (Sapindaceae) from East and Central Africa. Kew Bull. 52, 719-723.

Davies, F.G., Verdcourt, B., 1998. Flora of Tropical East Africa: Sapindaceae. A.A. Balkema, Rotterdam.

Demesure, B., Sodzi, N., Petit, R.J., 1995. A set of universal primers for amplification of polymorphic noncoding regions of mitochondrial and chloroplast DNA in plants. Mol. Ecol. 4, 129-131.

Doyle, J.J., Doyle, J.L., 1987. A rapid DNA isolation procedure for small quantities of fresh leaf tissue. Phytochem. Bull. 19, 11-15.

Driskell, A.C., Ané, C., Burleigh, J.G., McMahon, M.M., O’Meara, B.C., Sanderson, M.J. 2004. Prospects for building the Tree of Life from large sequence databases. Science 306, 1172-1174.

Edwards, K.J., Gadek, P.A., 2001. Evolution and biogeography of Alectryon (Sapindaceae). Mol. Phylogenet. Evol. 20, 14-26.

Estabrook, G.F., 1992. Evaluating undirected positional congruence of individual taxa between two estimates of the phylogenetic tree for a group of taxa. Syst Biol. 41, 172-177.

Estabrook, G.F., McMorris, F.R., Meacham, C.A., 1985. Comparison of undirected phylogenetic trees based on subtrees of four evolutionary units. Syst. Zool. 34 193-200.

Farris, J.S., Källersjö, M., Kluge, A.G., Bult, C., 1994. Testing significance of incongruence. Cladistics 10, 315-319.

Felsenstein, J., 1985. Confidence-limits on phylogenies - an approach using the bootstrap. Evolution 39, 783-791.

Ferrucci, M.S., 1991. Flora del Paraguay. Sapindaceae, vol. 16. Héliographia SA, Genève.

Ferrucci, M.S., 1998. Flora fanerogamica Argentina. Sapindaceae 52, 1-165.

Forest, F., Drouin, J.N., Charest, R., Brouillet, L., Bruneau, A., 2001. A morphological phylogenetic analysis of Aesculus L. and Billia Peyr. (Sapindaceae). Can. J. Bot. 79, 154-169.

Gadek, P.A., Fernando, E.S., Quinn, C.J., Hoot, S.B., Terrazas, T., Sheahan, M.C., Chase M.W., 1996. Sapindales: molecular delimitation and infraordinal groups. Am. J. Bot. 83, 802-811.

George, A.S., Erdtman, G., 1969. A revision of the genus Diplopeltis Endl. (Sapindaceae). Grana Palynologica 9, 92-109.

Hall, T.A., 1999. Bioedit: a user-friendly biological sequence alignment editor and analysis program for Windows 95/98/NT. Nucleic Acids Symp. Ser. 41, 95-98.

Hamilton, M.B., 1999. Four primer pairs for the amplification of chloroplast intergenic regions with intraspecific variation. Mol. Ecol. 8, 521-523.

Harrington, M.G., Edwards, K.J., Johnson, S.A., Chase, M.W., Gadek, P.A., 2005 Phylogenetic inference in Sapindaceae sensu lato using plastid matK and $r b c L$ DNA sequences. Syst. Bot. 30, 366-382.

Huelsenbeck, J.P., 1991. When are fossils better than extant taxa in phylogenetic analysis? Syst. Zool. 40, 458-469.

Judd, W.S., Sanders, R.W., Donoghue, M.J., 1994. Angiosperm family pairs: preliminary phylogenetic analyses. Harv. Pap. Bot. 5, 1-51.

Klaassen, R., 1999. Wood anatomy of the Sapindaceae. Int. Assoc. Wood. Anat. J. 2 (Suppl.), 1-214.
Kluge, A.G., 1989. A Concern for evidence and a phylogenetic hypothesis of relationships among Epicrates (Boidae, Serpentes). Syst. Zool. 38, 7-25.

Mabberley, D.J., 2008. Mabberley's Plant-Book. Cambridge University Press, Cambridge.

Morrison, D.A., 2006. Multiple sequence alignment for phylogenetic purposes. Aust. Syst. Bot. 19, 479-539.

Muellner, A.N., Samuel, R., Johnson, S.A., Cheek, M., Pennington, T.D., Chase, M.W., 2003. Molecular phylogenetics of Meliaceae (Sapindales) based on nuclear and plastid DNA sequences. Am. J. Bot. 90, 471-480.

Muellner, A.N., Samuel, R., Chase, M.W., Pannell, C.M., Greger, H., 2005. Aglaia (Meliaceae): an evaluation of taxonomic concepts based on DNA data and secondary metabolites. Am. J. Bot. 92, 534-543.

Muellner, A.N., Savolainen, V., Samuel, R., Chase, M.W., 2006. The mahogany family "out-of-Africa": divergence time estimation, global biogeographic patterns inferred from plastid $r b c L$ DNA sequences, extant, and fossil distribution of diversity. Mol. Phylogenet. Evol. 40, 236-250.

Muellner, A.N., Vassiliades, D.D., Renner, S.S., 2007. Placing Biebersteiniaceae, a herbaceous clade of Sapindales, in a temporal and geographic context. Pl. Syst. Evol. 266, 233-252.

Müller, J., Leenhouts, P.W., 1976. A general survey of pollen types in Sapindaceae in relation to taxonomy. In: Ferguson, I.K., Müller, J. (Eds.), The Evolutionary Significance of the Exine. Academic Press, London, pp. 407-445.

Munzner, T., Guimbretiere, F., Tasiran, S., Zhang, L., Zhou, Y., 2003. TreeJuxtaposer: scalable tree comparison using focus, plus context with guaranteed visibility. ACM Trans. Graph. 22, 453-462.

Nixon, K.C., 1999. The Parsimony Ratchet, a new method for rapid parsimony analysis. Cladistics $15,407-414$.

Perrier, X., Flori, A., Bonnot, F., 2003. Data analysis methods. In: Hamon, P., Seguin, M., Perrier, X., Glaszmann, J.C. (Eds.), Genetic diversity of cultivated tropical plants. Science Publishers, Montpellier, Enfield, pp. 43-76.

Phillipe, H., Snell, E.A., Bapteste, E., Lopez, P., Holland, P.W.H., Casane, D., 2004. Phylogenomics of eukaryotes: impact of missing data on large alignments. Mol. Biol. Evol. 21, 1740-1752.

Posada, D., Crandall, K.A., 1998. Modeltest: testing the model of DNA substitution. Bioinformatics 14, 817-818.

Radlkofer, L., 1890. Ueber die Gliederung der Familie der Sapindaceen. Sitz. - Ber. Akad. Wiss. Munchen 20, 105-379.

Radlkofer, L., 1933. Sapindaceae. In: Engler, A. (Ed.), Das Pflanzenreich IV, 165 (Heft 98a-h). Leipzig, Verlag von Wilhelm Engelmann.

Rauschert, S., 1982. Nomina nova generica et combinationes novae Spermatophytorum et Pteridophytorum. Taxon 31, 554-563.

Richardson, J.E., Fay, M.F., Cronk, Q.C.B., Bowman, D., Chase, M.W., 2000a. A phylogenetic analysis of Rhamnaceae using $r b c L$ and $t r n L-F$ plastid DNA sequences. Am. J. Bot. 87, 1309-1324.

Richardson, J.E., Fay, M.F., Cronk, Q.C.B., Chase, M.W., 2000b. A revision of the tribal classification of Rhamnaceae. Kew Bull. 55, 311-340.

Salamin, N., Chase, M.W., Hodkinson, T.R., Savolainen, V., 2003. Assessing internal support with large phylogenetic DNA matrices. Mol. Phylogenet. Evol. 27, 528539.

Savolainen, V., Fay, M.F., Albach, D.C., Backlund, A., van der Bank, M., Cameron, K.M., Johnson, S.A., Lledó, M.D., Pintaud, J.-C., Powell, M., Sheahan, M.C., Soltis, D.E. Soltis, P.S., Weston, P., Whitten, W.M., Wurdack, K.J., Chase, M.W., 2000. Phylogeny of the eudicots: a newly complete familial analysis based on $r b c L$ gene sequences. Kew Bull. 55, 257-309.

Sikes, D.S., Lewis, P.O., 2001. PAUPRAT, University of Connecticut, Storrs.

Soltis, D.E., Soltis, P.S., 1998. Choosing an approach and appropriate gene for phylogenetic analysis. In: Soltis, D.E., Soltis, P.E., Doyle, J.J. (Eds.), Molecular Systematics of Plants II: DNA Sequencing. Kluwer, Boston, Massachusetts, USA pp. $1-42$.

Soltis, D.E., Soltis, P.S., Chase, M.W., Mort, M.E., Albach, T.D., Zanis, M., Savolaninen, V., Hahn, W.H., Hoot, S.B., Fay, M.F., Axtell, M., Swensen, S.M., Prince, L.M., Kress, W.J., Nixon, K.C., Farris, J.S., 2000. Angiosperm phylogeny inferred from $18 \mathrm{~S}$ rDNA, rbcL, and atpB sequences. Bot. J. Linn. Soc. 133, 381-461.

Stamatakis, A., 2006. RAxML-VI-HPC: maximum likelihood-based phylogenetic analyses with thousands of taxa and mixed models. Bioinformatics 22, 26882690.

Stamatakis, A., Hoover, P., Rougemont, J., 2008. A rapid bootstrap algorithm for the RAxML web-servers. Syst. Biol. 57, 758-771.

Swofford, D.L., 2002. PAUP*: Phylogenetic Analysis using Parsimony (* and Other Methods), Version 4. Sinauer Associates, Sunderland, Massachusetts.

Taberlet, P., Gielly, L., Pautou, G., Bouvet, J., 1991. Universal primers for amplification of three noncoding regions of chloroplast DNA. Plant Mol. Biol. 17, 1105-1109.

Takhtajan, A., 1987. Systema Magnoliophytorum. Soviet Sciences Press, Leningrad.

Thomas, D.W., Harris, D.J., 1999. New Sapindaceae from Cameroon and Nigeria. Kew Bull. 54, 951-957.

Thompson, J.D., Gibson, T.J., Plewniak, F., Jeanmougin, F., Higgins, D.G., 1997. The Clustal X Windows interface: flexible strategies for multiple sequence alignment aided by quality analysis tools. Nucleic Acids Res. 25, 4876-4882.

Thorne, R.F., 2000. The classification and geography of the flowering plants: dicotyledons of the class Angiospermae. Bot. Rev. 66, 441-647.

Thorne, R.F., 2007. An update classification of the class Magnoliopsida ("Angiospermae"). Bot. Rev. 73, 67-182.

Umadevi, I., Daniel, M., 1991. Chemosystematics of the Sapindaceae. Feddes Repertorium 102, 607-612. 
van der Ham, R.W., 1990. Nephelieae pollen (Sapindaceae): form, function, and evolution. Leiden Botanical Series 13, 1-255.

van Welzen, P.C., 1990. Guioa Cav. (Sapindaceae): taxonomy, phylogeny, and historical biogeography. Leiden Botanical Series 12, 1-315.

White, T.J., Bruns, T., Lee, S., Taylor, J., 1990. Amplification and direct sequencing of fungal ribosomal RNA genes for phylogenetics. In: Innis, M., Gelfand, D., Sninsky, J., White, T. (Eds.), PCR Protocols: a Guide to Methods and Applications. Academic Press, San Diego, pp. 315-322.

Wiens, J.J., 1998. Does adding characters with missing data increase or decrease phylogenetic accuracy? Syst. Biol. 47, 625-640.

Wiens, J.J., 2003. Missing data, incomplete taxa, and phylogenetic accuracy. Syst. Biol. 52, 528-538

Wiens, J.J., 2005. Can incomplete taxa rescue phylogenetic analyses from longbranch attraction? Syst. Biol. 54, 731-742.
Wiens, J.J., 2006. Missing data and the design of phylogenetic analyses. J. Biomed Inform. 39, 34-42.

Wiens, J.J., Reeder, T.W., 1995. Combining data sets with different numbers of taxa for phylogenetic analysis. Syst. Biol. 44, 548-558.

Wilkinson, M. Cotton, J.A. Creevey, C., Eulenstein, O., Harris, S.R. Lapointe, FJ. Levasseur, C., McInerney, J.O., Pisani, D., Thorley, J.L., 2005. The shape of supertrees to come: tree shape related properties of fourteen supertree methods. Syst. Biol. 54, 419-431.

Xia, N., Gadek, P.A., 2007. Flora of China. 12, 1-6 Available from: <www.efloras.org> Xiang, Q.-Y., Crawford, D.J., Wolfe, A.D., Tang, Y.-C., DePamphilis, C.W., 1998. Origin and biogeography of Aesculus L. (Hippocastanaceae): a molecular phylogenetic perspective. Evolution 52, 988-997.

Yang,Z.H., 1993. Maximum-likelihood-estimation of phylogeny from DNA-sequences when substitution rates differ over sites. Mol. Biol. Evol. 10, 1396-1401. 